\title{
Proteomic analysis of mare follicular fluid during late follicle development
}

Somayyeh Fahiminiya ${ }^{1,2,3,4}$, Valérie Labas ${ }^{1,2,3,4,5}$, Stéphane Roche ${ }^{6,7}$, Jean-Louis Dacheux ${ }^{1,2,3,4}$ and Nadine Gérard ${ }^{1,2,3,4^{*}}$

\begin{abstract}
Background: Follicular fluid accumulates into the antrum of follicle from the early stage of follicle development. Studies on its components may contribute to a better understanding of the mechanisms underlying follicular development and oocyte quality. With this objective, we performed a proteomic analysis of mare follicular fluid. First, we hypothesized that proteins in follicular fluid may differ from those in the serum, and also may change during follicle development. Second, we used four different approaches of Immunodepletion and one enrichment method, in order to overcome the masking effect of high-abundance proteins present in the follicular fluid, and to identify those present in lower abundance. Finally, we compared our results with previous studies performed in mono-ovulant (human) and poly-ovulant (porcine and canine) species in an attempt to identify common and/or species-specific proteins.
\end{abstract}

Methods: Follicular fluid samples were collected from ovaries at three different stages of follicle development (early dominant, late dominant and preovulatory). Blood samples were also collected at each time. The proteomic analysis was carried out on crude, depleted and enriched follicular fluid by 2D-PAGE, 1D-PAGE and mass spectrometry.

Results: Total of 459 protein spots were visualized by 2D-PAGE of crude mare follicular fluid, with no difference among the three physiological stages. Thirty proteins were observed as differentially expressed between serum and follicular fluid. Enrichment method was found to be the most powerful method for detection and identification of low-abundance proteins from follicular fluid. Actually, we were able to identify 18 proteins in the crude follicular fluid, and as many as 113 in the enriched follicular fluid. Inhibins and a few other proteins involved in reproduction could only be identified after enrichment of follicular fluid, demonstrating the power of the method used. The comparison of proteins found in mare follicular fluid with proteins previously identified in human, porcine and canine follicular fluids, led to the identification of 12 common proteins and of several species-specific proteins.

Conclusions: This study provides the first description of mare follicular fluid proteome during the late follicle development stages. We identified several proteins from crude, depleted and enriched follicular fluid. Our results demonstrate that the enrichment method, combined with 2D-PAGE and mass spectrometry, can be successfully used to visualize and further identify the low-abundance proteins in the follicular fluid.

Keywords: mare, ovary, follicular fluid, 2D-PAGE, hexapeptide ligand library

\section{Background}

Follicular fluid accumulates into the follicle antrum starting with the early stage of follicle development. Plenty of evidence suggests that follicular fluid proteins originate from two sources: blood and surrounding

\footnotetext{
* Correspondence: Nadine.Gerard@tours.inra.fr

${ }^{1}$ INRA, UMR 6175 Physiologie de la Reproduction et des Comportements, F37380 Nouzilly, France

Full list of author information is available at the end of the article
}

somatic cell layers (granulosa and theca cells) (Figure 1). Earlier studies showed that the "blood-follicle barrier" is permeable for proteins below $500 \mathrm{kDa}$ [1], and most proteins and other components easily pass through the basal lamina to enter the antrum, or escape towards circulating blood. Indeed, ovarian cells produce and secrete a number of soluble factors such as steroids, growth factors and other peptidergic factors into the follicular fluid [2]. The presence of all these factors is related to the
C Biomed Central

(C) 2011 Fahiminiya et al; licensee BioMed Central Ltd. This is an Open Access article distributed under the terms of the Creative Commons Attribution License (http://creativecommons.org/licenses/by/2.0), which permits unrestricted use, distribution, and reproduction in any medium, provided the original work is properly cited. 


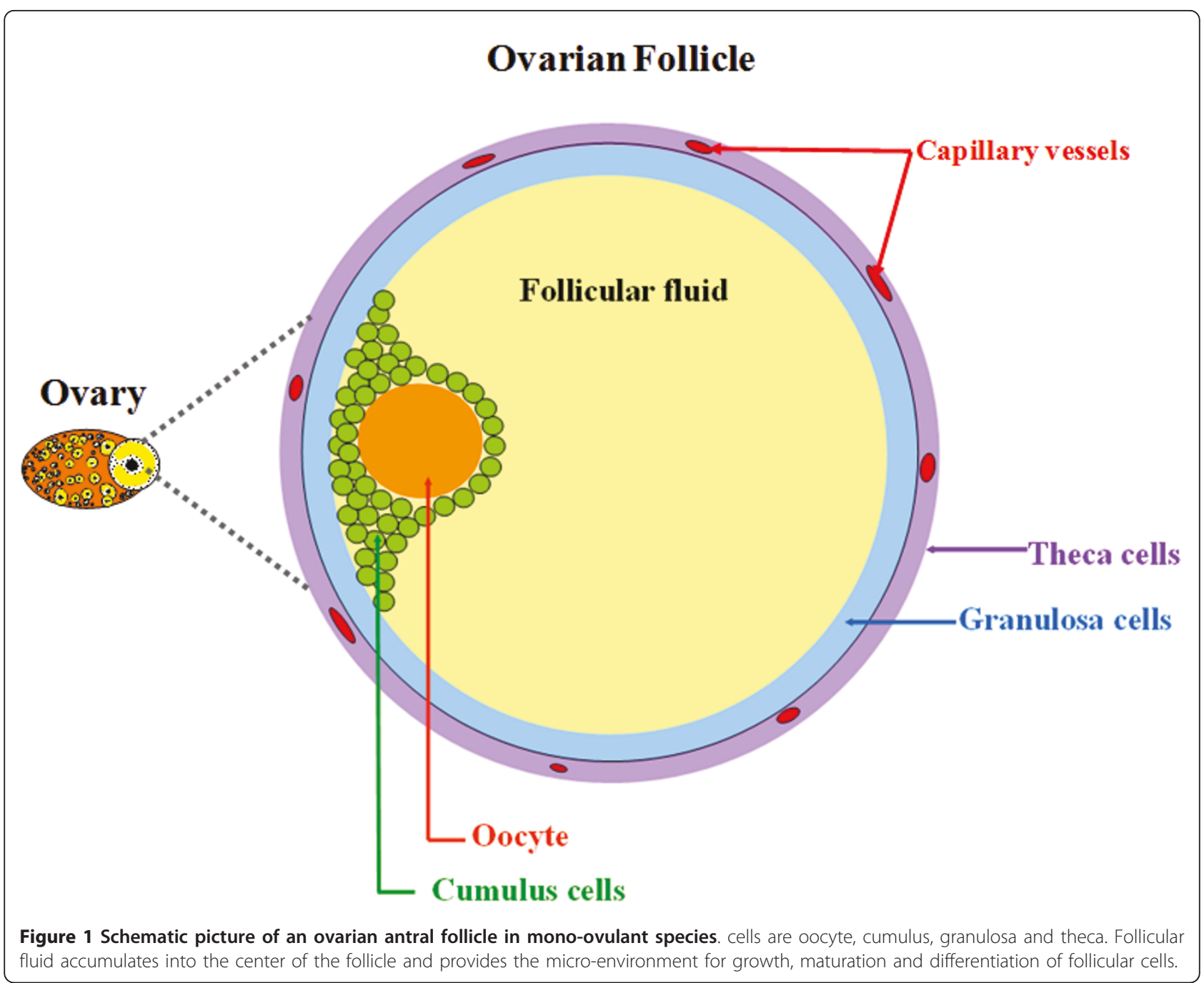

metabolic activity of ovarian cells, and reflects the physiological status of the follicle. Furthermore, numerous studies have clearly demonstrated that these substances are essential for oocyte maturation and fertilization, granulosa cell proliferation and differentiation, and eventual ovulation and luteinisation [3]. However, the role in ovarian function played by many of these factors is still unknown. The study of follicular fluid components may contribute, to an understanding of the mechanisms involved in follicle differentiation and development.

Proteomic analysis of body fluids can have a helpful information for biomarkers discovery and treatment development [4]. To date, the most comprehensive proteomic analyses were performed on human follicular fluid. Spitzer et al. (1996) were first in studying comparatively the complex protein patterns of fluid from mature and immature human follicles [5]. Then, the study of Anahory et al. (2002) resulted in the identification of three proteins of human follicular fluid (thioredoxin peroxidase 1, transthyretin and retinol-binding protein) [6]. Three years later, Lee et al. (2005) identified four other proteins (hormone sensitive lipase, unnamed protein product 1 , unnamed protein product 2 , and apolipoprotein A-IV) in human follicular fluid [7]. Angelucci et al. (2006) performed an interesting and comprehensive proteomic study on human follicular fluid from women undergoing in vitro fertilization for male associated infertility [8]. The authors identified many proteins, mainly acute phase proteins and several proteins with antioxidant properties. Finally in 2010, Jarkovska et al. [9] used proteomic approach to study follicular fluid from women undergoing successful in vitro fertilization. They showed that proteins involved in the complement cascade may be associated with follicle/oocyte maturation. Proteomic analyses were also performed on follicular fluid of domestic animals, including bovine (5 proteins identified; Mortarino et al. 1999), porcine (53 proteins identified; 
Bijttebier et al. 2009) and canine (21 proteins identified; Fahiminiya et al. 2010) [10-12].

The ovarian physiology of the mare, compared to that of other mono-ovulant species, exhibits some uncommon features. Indeed, the ovulatory LH surge occurs as a progressive rise over several days, with a peak occurring one day after ovulation $[13,14]$. Moreover, the assisted reproduction techniques such as in vitro oocyte maturation, fertilization and embryo development have lower success rate than in bovine or human [15]. Investigations on the protein content of mare follicular fluid may provide useful information about the mechanisms underlying follicular development and oocyte maturation, and may lead to improvements in culture conditions and eventual success of assisted reproduction in this species.

We performed a proteomic analysis of the mare follicular fluid. Our study was divided into three parts: first, we hypothesized that proteins within mare follicular fluid differ from those in blood serum, and also could change during late follicle development leading to ovulation. For this purpose, we analyzed the global protein profile of both mare follicular fluid and serum, and then compared three different stages of the follicle development (early dominant, late dominant and preovulatory). Second, we used four different approaches of Immunodepletion and one of enrichment, to overcome the masking effect of high-abundance proteins present in the follicular fluid. Finally, we hypothesized that follicular fluid may contain a fixed set of proteins, regardless of species, and a variable set of proteins related to the specific physiological features of each species. Therefore, we compared our results with previous data obtained in mono-ovulant (human) and poly-ovulant (porcine and canine) species, to identify common and/or species-specific proteins.

\section{Results}

\section{Proteomic analysis of crude mare follicular fluid}

The 2D-PAGE method was used to characterize the protein profile of mare follicular fluid. The 2D patterns showed a total of 459 protein spots separated between pI (3-10) and molecular mass (10-200 kDa) intervals (Figure 2). Among them, 27 were excised from the gels and analysed by mass spectrometry. Assigned proteins are indicated on the 2D map (Figure 2) and are reported in Table 1. According to this result, 27 (100\%) of the excised spots were identified, which represented 18 unique proteins. The high-abundant proteins, albumin (ALB) and immunoglobulin heavy chains (IGHC1) appeared as intense and large spots in protein patterns of mare follicular fluid (indicated by dotted rectangles in Figure 2). In addition, 4 (14.81\%) proteins (albumin, immunoglobulin heavy chains, alpha-1-antitrypsin and haptoglobin precursor) were identified as multiple spots (indicated by dark circles in Figure 2).

\section{Comparison of mare follicular fluid protein patterns with serum and between three stages of follicular development}

The 2D-PAGE method was applied to compare the protein patterns of mare follicular fluid samples collected from early dominant (size of follicles: $25.67 \pm 0.67 \mathrm{~mm}$, $\mathrm{n}=3$ ), late dominant (size of follicles: $34.67 \pm 1.20 \mathrm{~mm}$, $\mathrm{n}=3$ ) and preovulatory (size of follicles: $39.33 \pm$ $1.76 \mathrm{~mm}, \mathrm{n}=3$ ) follicles. The $2 \mathrm{D}$ patterns of protein expression appeared largely similar in the three stages, and the image analysis revealed no differentially expressed proteins during follicle development. Moreover, the patterns of protein expression between follicular fluid and serum appeared largely similar but some clear differences were obvious (Figure 3A). We observed 30 differential protein spots between mare follicular fluid and serum, one (spot $\mathrm{N}^{\circ} 9$ ) was present only in follicular fluid, eight spots were only in serum (boxes 3, 5 and spot $\mathrm{n}^{\circ} 143$ ) and 21 spots (boxes 1, 2, 4 and spots $\mathrm{N}^{\circ} 232$ and 194) were less intense in follicular fluid than in serum (Figure 3B). These spots were excised from the gels and analysed by mass spectrometry. The result of protein identification showed that the spots number 232 and boxes 1 and 2 correspond to antithrombin-III, alpha-2macroglobulin and ceruloplasmin, respectively. Other spots were not identified positively in this study.

\section{Pre-fractionation of mare follicular fluid before proteomic analysis \\ Depletion of mare follicular fluid using four different Immunodepletion columns}

In order to clear the follicular fluid from high-abundance proteins, and to attempt to visualize and identify some low-abundance ones, four Immunodepletion columns, developed to capture one (ProteomeLab IgY-HSA), six (MARS-6), twelve (ProteomeLab IgY-12) or twenty (ProteoPrep 20) high-abundance proteins from human serum (Additional file 1), were used in this study. Under our experimental conditions and considering protein assays, higher depletion efficiencies were obtained with the two IgY columns (81\% for ProteomeLab IgY-12 and $75.5 \%$ for ProteomeLab IgY-HSA), than with the two other columns based on IgG (70.58\% and 55.94\% for MARS- 6 and ProteoPrep 20, respectively). As shown in Additional file 2, the 2D-PAGE patterns of depleted fractions revealed that ProteomeLab IgY-HSA and MARS-6 were more efficient in eliminating albumin from mare follicular fluid than the two other columns tested. The lowest percentage of depletion efficiency observed for the ProteoPrep 20 column was confirmed by 2D-PAGE, since this column depleted neither ALB nor IGHC1 from the mare follicular fluid. Eighteen protein spots, preferentially chosen by localization, were excised from MARS-6 2DPAGE (Figure 4) and analysed by mass spectrometry. 


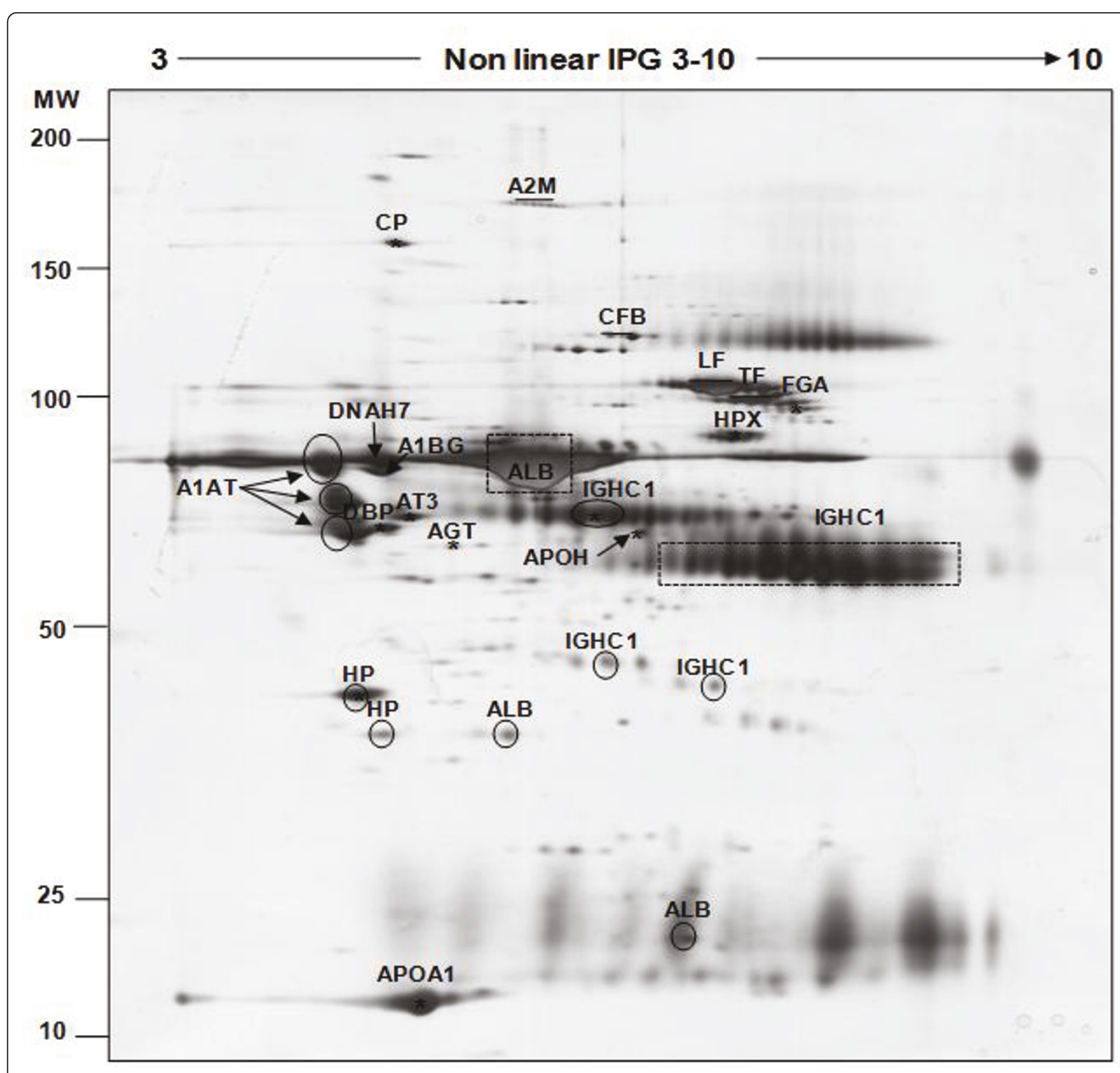

Figure 2 Silver stained 2D-PAGE of crude mare follicular fluid. $100 \mu \mathrm{g}$ of proteins were applied to a non-linear IPG strip (pl 3-10) in the first dimension and separated on a SDS-PAGE (10\%) gel in the second dimension (Molecular Weight: 10-200 kDa range). The positions of the highabundance proteins albumin (ALB) and immunoglobulin heavy chain (IGHC1) are indicated by dark dotted rectangles or dark circles. All other identified proteins are named and their characteristics are shown in Table 1.

Out of them, $77 \%(14 / 18)$ were successfully identified as 12 unique proteins (Table 2).

Among these proteins, one (immunoglobulin gamma 1 heavy chain constant region) was identified in 3 different locations on the gel (rectangle in Figure 4 shows the common location of IGHC1 on 2D-PAGE). In addition, one single protein (histidine-rich glycoprotein) was identified from an excised spot in the region initially occupied by albumin, which clearly shows the masking effect of albumin as a high-abundant protein.

\section{Enrichment of mare follicular fluid using Hexapeptide} ligand library

Hexapeptide ligand library (marketed as ProteoMiner ${ }^{\circledR}$ ) column was used to enrich mare follicular fluid and 2DPAGE was performed to visualize the proteins between 3$10 \mathrm{pH}$ intervals (Figure 5). Thirty-seven protein spots were excised from the gels and analysed by mass spectrometry. Thirty-three (89\%) were successfully identified, which correspond to 17 unique proteins (Table 3 ) and one unnamed protein product $(\mathrm{UN}$ : accession number = gi $\mid 28317$; 
Table 1 Identified proteins of crude mare follicular fluid separated by 2D-PAGE (pl: 3-10; MW: 10-200; silver staining)

\begin{tabular}{|c|c|c|c|c|c|c|c|}
\hline \multirow[t]{2}{*}{ Gene } & \multirow[t]{2}{*}{ Accession $\mathrm{N}^{\circ 1}$} & \multirow[t]{2}{*}{ Protein name } & \multirow[t]{2}{*}{ Score $^{2}$} & \multicolumn{2}{|c|}{ Theoretical } & \multirow[t]{2}{*}{ Peptide $\mathrm{N}^{03}$} & \multirow[t]{2}{*}{ Sequence coverage $(\%)^{4}$} \\
\hline & & & & $\mathrm{pl}^{3}$ & $\operatorname{Mr}(\mathrm{Da})^{3}$ & & \\
\hline A1BG & gi|194216172 & Alpha-1-B glycoprotein & 374 & 8.74 & 68222 & 10 & 21 \\
\hline $\mathrm{A} 2 \mathrm{M}$ & gi|194211675 & Alpha-2-macroglobulin & 1389 & 6.24 & 163911 & 21 & 25 \\
\hline AGT & gi|194206059 & Angiotensinogen & 50 & 7.06 & 70056 & 1 & 3 \\
\hline ALB & gi|76363596 & Albumin & 294 & 5.89 & 68494 & 31 & 43 \\
\hline ALB & gi|76363596 & Albumin & 112 & 5.89 & 68494 & 2 & 4 \\
\hline ALB & gi|399672 & Preproalbumine & 91 & 5.95 & 68554 & 2 & 4 \\
\hline APOA1 & gi|3915607 & Apolipoprotein A-I & 105 & 5.2 & 30178 & 2 & 7 \\
\hline $\mathrm{APOH}$ & gi|149723623 & Apolipoprotein H & 33 & 8.43 & 38511 & 1 & 2 \\
\hline AT3 & gi|179161 & Antithrombin III & 92 & 6.32 & 52585 & 2 & 5 \\
\hline DNAH7 & gi|149699076 & $\begin{array}{l}\text { Similar to dynein, axonemal, heavy polypeptide } \\
7 \text { isoform } 1\end{array}$ & 232 & 5.5 & 61446 & 5 & 11 \\
\hline CFB & gi|149732066 & Complement factor B & 141 & 6.75 & 85930 & 3 & 4 \\
\hline$C P$ & gi|180249 & Ceruloplasmin & 48 & 5.29 & 97637 & 1 & 1 \\
\hline DBP & gi|73975213 & Vitamin D-binding protein & 39 & 5.2 & 52940 & 1 & 1 \\
\hline FGA & gi|3789960 & Fibrinogen alpha & 57 & 6.45 & 49477 & 2 & 4 \\
\hline HP & gi|149699777 & Haptoglobin precursor & 103 & 6.24 & 45176 & 5 & 9 \\
\hline HP & gi|149699777 & Haptoglobin precursor & 112 & 5.59 & 38441 & 3 & 9 \\
\hline HPX & gi|386789 & Hemopexin & 32 & 6.57 & 51512 & 1 & 1 \\
\hline $\lg G$ & gi|9858135 & Immunoglobulin G1b & 70 & 5.7 & 46904 & 2 & 10 \\
\hline IGHC1 & gi|15020816 & Immunogobulin gamma 1 & 30 & 7.68 & 37415 & 1 & 2 \\
\hline IGHC1 & gi|15020816 & Immunogobulin gamma 1 & 30 & 7.68 & 37415 & 1 & 2 \\
\hline IGHC1 & gi|15020816 & Immunogobulin gamma 1 & 30 & 7.68 & 37415 & 1 & 2 \\
\hline IGHC1 & gi|15020816 & Immunogobulin gamma 1 & 30 & 7.68 & 37415 & 1 & 2 \\
\hline LF & gi|13431954 & Lactoferrine & 54 & 8.66 & 77162 & 1 & 3 \\
\hline A1AT & gi|194225326 & Alpha-1-antitrypsin & 45 & 5.23 & 46913 & 2 & 3 \\
\hline A1AT & gi|194225326 & Alpha-1-antitrypsin & 398 & 5.31 & 46896 & 5 & 13 \\
\hline A1AT & gi|194225326 & Alpha-1-antitrypsin & 83 & 5.23 & 46913 & 3 & 5 \\
\hline TF & gi|3892525 & Transferrin & 219 & 8.6 & 6880 & 4 & 42 \\
\hline
\end{tabular}

${ }^{1}$ Accession $\mathrm{N}^{\circ}$ is an accession number from the NCBInr databases. ${ }^{2}$ Score is $-10^{*}$ Log $(\mathrm{P})$, where $\mathrm{P}$ is the probability that the observed match is a random event, it is based on NCBInr database using the MASCOT searching program. ${ }^{3}$ PI: isoelectric point; Mr: Molecular weight; Peptid N ${ }^{\circ}$ : Peptid number. ${ }^{4}$ Sequence coverage (\%) is based on number of peptide masses matched in NCBInr databases.

indicated by dark rectangle in Figure 5). In addition, 5 protein spots (indicated by dark circles in Figure 5) were not identified, most probably due to the low intensity of proteins resulting in low sequence coverage insufficient for identification.

In addition to the proteins identified in crude mare follicular fluid, this strategy allowed us to identify other proteins which were either cytosolic (ACT, SNX1, GAPDH, GPX) or secretory (AMBP, FCN1, CLU, C3, FGG, FGB, FH and PSP). Furthermore, 3 proteins (Fibrinogen $\beta$, complement regulator factor $\mathrm{H}$ and AMBP) were identified in the region initially occupied by heavy and light immunoglobulin chains.

The result of the shotgun separation method (1DPAGE-LC) that we performed on the enriched fraction of mare follicular fluid is shown in Figure 6A. The electrophoretic separation patterns of both reduced and unreduced conditions were similar, with estimated molecular weights ranging from less than $14 \mathrm{kDa}$ to greater than
$100 \mathrm{kDa}$. Both lanes were cut into 21 fragments, subjected to trypsin digestion and analyzed by mass spectrometry.

The major band visualized in unreduced conditions with molecular weights from 40 to $60 \mathrm{kDa}$ (excised bands from 13 to 16) was not present in reduced conditions. The result of protein identification in this region showed that the dominant proteins were mainly immunoglobulin gamma 1 heavy chain $(37 \mathrm{kDa})$, histidine-rich glycoprotein (42 kDa), apolipoprotein A-IV (43 kDa), alpha-1-antitrypsin $(46 \mathrm{kDa})$, fibrinogen A-alpha $(49 \mathrm{kDa})$, fibrinogen gamma $(51 \mathrm{kDa})$, vitronectin $(54 \mathrm{kDa})$, fibrinogen beta (55 kDa), EGF-containing fibulin-like extracellular matrix protein 1 isoform (55 kDA) and albumin/preproalbumin (68 kDa). In addition, we identified the same number of proteins $(n=88)$ from the 21 excised bands in both conditions (Additional files 3 \&4). Sixty-four were identified under both conditions, 24 proteins were identified only under reduced conditions, and 25 only under unreduced 


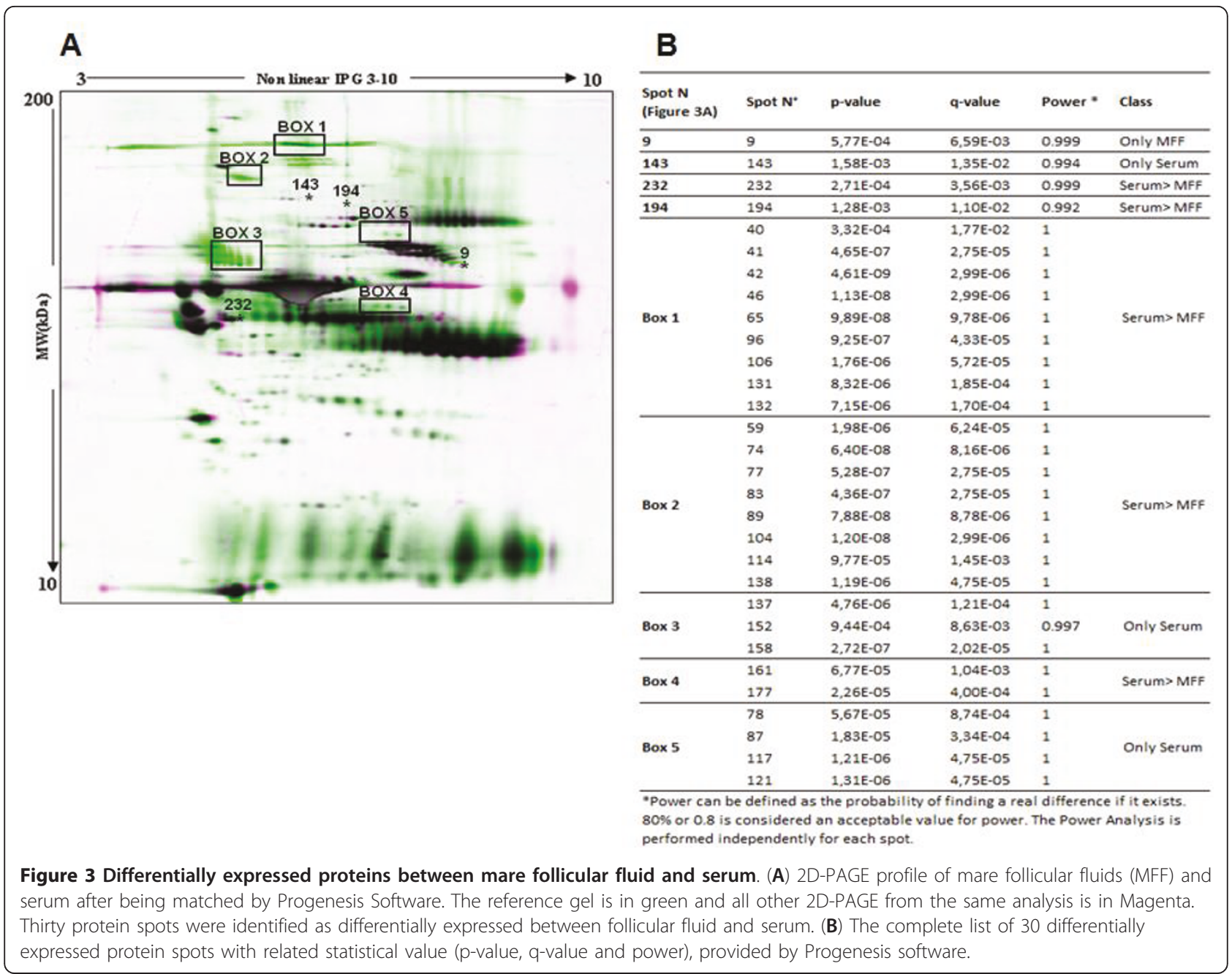

conditions (Figure 6B). Some of these 49 uncommon proteins were different isoform of the same family proteins (complement factors, immunoglobulin or inter-alpha globulin). Altogether, we were able to separate and identify proteins with a molecular mass of only $3 \mathrm{kDa}$ using unreduced conditions (plasma glutathione peroxidase), and 11 $\mathrm{kDa}$ under reduced conditions (Apolipoprotein C-II).

\section{Subcellular and functional annotation of mare follicular fluid proteome}

Bioinformatic analysis was performed on the mare follicular fluid proteome, i.e. on all proteins that we identified in the present study, in order to determine their subcellular localization and their molecular function. The analysis of subcellular localization demonstrated that as many as $83 \%$ of proteins were localized in the extracellular region (Figure 7A). The rest were localized in the intracellular compartment, including cytoplasm, cytoskeleton, plasma membrane or nucleus.
The functional annotation showed that proteins were involved in various molecular functions (Figure 7B). A total of 18 groups of molecular functions were classified. The two most abundant include $25 \%$ of the proteins, involved either in immunity and defense $(14 \%)$ or transport (11\%). The complement system and blood coagulation group together represent $17 \%$ of the proteins. In contrast, proteins involved in lipid-fatty acid-steroid metabolism or in reproductive system development and function only represent $6 \%$ and $2 \%$, of the identified proteins, respectively. In addition, a substantial number of identifications concerned proteins with inhibitory function of serine proteases (e.g. plasma serine protease inhibitor and alpha-1 antitrypsin), cystein proteases (fetuin-B) and serine-type endopeptidase (inter-alphatrypsin inhibitor heavy chain $\mathrm{H} 1 / \mathrm{H} 2 / \mathrm{H} 4$, protein $\mathrm{AMBP}$, protein Z-dependent protease inhibitor). The list of proteins with their function and subcellular localization were summarized in Additional file 5. 


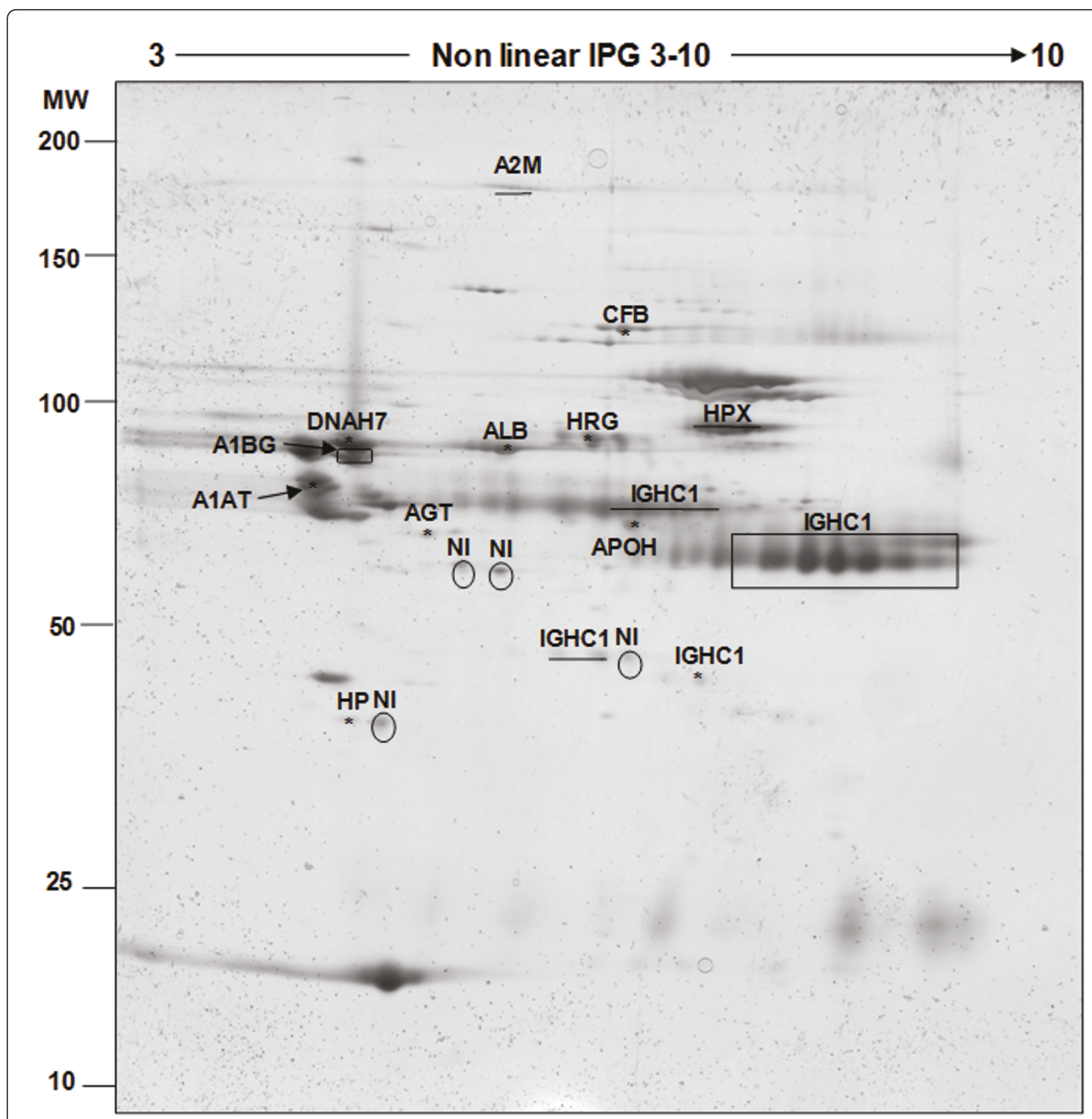

Figure 4 Identification of proteins from depleted mare follicular fluid by MARS-6. $100 \mu \mathrm{g}$ of proteins were applied to a non-linear IPG strip (pl 3-10) in the first dimension and separated on SDS-PAGE (10\%) (Molecular Weight: 10-200 kDa range). All identified proteins are named and their characteristics are shown in Table 2. Rectangle shows the common location of IGHC1 on the 2D-PAGE. NI: Not-Identified proteins.

\section{Overlapping of mare follicular fluid proteins with those} from three other species

We compared our results with other follicular fluid proteomic studies performed in three mammalian species including canine, human and porcine (Table 4) $[8,9,11,12]$. The Venn diagram (Figure 8 ) revealed that a set of 12 proteins were common to the four species. In addition, 17 proteins were present in at least three out of four species.
We also observed that $60,20,13$ and 5 proteins were identified only in mare (MFF), human (HFF), porcine (PFF) and canine (CFF) follicular fluid, respectively. The list of these species specific proteins (Table 5) showed that some of them were various fragment of high abundant proteins like immunoglobulins, complement factors or apolipoprotein. This may be due to various experimental procedures on the samples. Interestingly, the proteins related to 
Table 2 Identified proteins of mare follicular fluid after depletion with MARS-6 and separation by 2D-PAGE (pl: 3-10; MW: 10-200; silver staining)

\begin{tabular}{|c|c|c|c|c|c|c|c|}
\hline \multirow[t]{2}{*}{ Gene } & \multirow[t]{2}{*}{ Accession $\mathrm{N}^{\circ} 1$} & \multirow[t]{2}{*}{ Protein name } & \multirow[t]{2}{*}{ Score $^{2}$} & \multicolumn{2}{|c|}{ Theoretical } & \multirow[t]{2}{*}{ Peptide $\mathrm{N}^{03}$} & \multirow[t]{2}{*}{ Sequence coverage $(\%)^{4}$} \\
\hline & & & & $\overline{p l^{3}}$ & $\operatorname{Mr}(\mathrm{Da})^{3}$ & & \\
\hline A1AT & gi|194225326 & Alpha-1-antitrypsin & 398 & 5.31 & 46896 & 6 & 13 \\
\hline A1BG & gi|194216172 & Alpha-1B-glycoprotein & 374 & 8.74 & 68222 & 8 & 21 \\
\hline $\mathrm{A} 2 \mathrm{M}$ & gi|194211675 & Alpha-2-macroglobulin & 1406 & 6.24 & 163911 & 25 & 26 \\
\hline AGT & gi|194206059 & Angiotensinogen & 50 & 7.06 & 70056 & 1 & 3 \\
\hline ALB & gi|76363596 & Serum albumin precursor & 112 & 5.89 & 68494 & 2 & 4 \\
\hline $\mathrm{APOH}$ & gi|149723623 & Apolipoprotein $\mathrm{H}$ & 33 & 8.43 & 38511 & 1 & 2 \\
\hline CFB & gi|149732066 & B-factor, properdin & 139 & 6.75 & 85930 & 2 & 4 \\
\hline DNAH7 & gi|149699076 & Dynein, axonemal, heavy polypeptide 7 isoform 1 & 232 & 5.5 & 61446 & 5 & 11 \\
\hline $\mathrm{HP}$ & gi|149699777 & Haptoglobin precursor & 112 & 5.59 & 38441 & 3 & 9 \\
\hline HPX & gi|149719403 & Hemopexin & 122 & 7.58 & 51324 & 3 & 6 \\
\hline HRG & gi|194222677 & Histidine-rich glycoprotein & 245 & 7.64 & 42955 & 5 & 16 \\
\hline IGHC1 & gi|15020816 & $\begin{array}{l}\text { Immunogobulin gamma } 1 \text { heavy chain constant } \\
\text { region }\end{array}$ & 31 & 7.68 & 37415 & 1 & 2 \\
\hline
\end{tabular}

${ }^{1}$ Accession $\mathrm{N}^{\circ}$ is an accession number from the NCBInr databases. ${ }^{2}$ Score is $-10^{*}$ Log $(\mathrm{P})$, where $\mathrm{P}$ is the probability that the observed match is a random event, it is based on NCBInr database using the MASCOT searching program. ${ }^{3}$ PI: isoelectric point; Mr: Molecular weight; Peptid $\mathrm{N}^{\circ}$ : Peptid number. ${ }^{4}$ Sequence coverage (\%) is based on number of peptide masses matched in NCBInr databases.

reproduction (inhibins), were identified only after enrichment of mare follicular fluid (present study). Finally, all the identified proteins from follicular fluid of the four species were combined and the protein list was improved from 113 (our study) to 154 (Additional file 6).

\section{Discussion}

Follicular fluid is the essential environment for growth and maturation of both ovarian somatic and germ cells. It contains substances implicated in cell differentiation, gamete quality and rupture of the follicular wall. One can reasonably expect that the determination of its protein composition will contribute to a better understanding of ovarian physiology and possibly to the regulation of follicular growth and development. We performed a proteomic analysis of the mare follicular fluid. Our study was split into three parts: first, we hypothesized that proteins of mare follicular fluid differ from serum and change during the late follicle development leading to ovulation. For this purpose, we analyzed the global protein profile of mare follicular fluid and compared the profiles of follicular fluid samples collected at three stages of final maturation of the follicle, as well as the serum profile. Second, we used different approaches of Immunodepletion and enrichment to deprive the follicular fluid of high-abundant proteins, to reduce their masking effect. Finally, we hypothesized that a fixed set of proteins would be present in follicular fluid regardless of the species, as well as a variable set of proteins which depends on the reproductive specificity of each species. Therefore, we compared our results with previous data obtained in mono-ovulant (human) and poly-ovulant (porcine and canine) species, in order to identify common and/or species-specific proteins.

\section{Crude mare follicular fluid proteomic analysis}

To reach our first objective, we used 2D-PAGE to characterize the global protein profile of mare follicular fluid, and mass spectrometry to identify some of the proteins. By combining these two techniques, we were able to identify 27 protein spots in the mare follicular fluid, corresponding to 18 unique proteins. The majority of identify proteins belonging to the high-abundance serum proteins (fragments of albumin, immunoglobulin G, transferrin, fibrinogen, antitrypsin, haptoglobin, apolipoprotein and ceruloplasmin). All of them had been identified previously in the follicular fluid from bovine [10], canine [11], human [8] and porcine [16]. Furthermore, four proteins, including albumin, immunoglobulin heavy chains, alpha-1-antitrypsin and haptoglobin precursor, were identified in multiple spots, probably due to posttranslational modifications and processing.

Many evidence supports the role of pituitary gonadotropins (FSH and $\mathrm{LH}$ ) in regulating numerous proteins implicated either in selection, ovulation or luteinization of the ovarian follicles [3]. Although most of them display a cellular localization, some have been localized in follicular fluid such as extracellular matrix glycoproteins $[17,18]$, proteinases $[19,20]$ and their inhibitors $[21,22]$. In the present investigation, we attempted to visualize and identify proteins in mare follicular fluid that may be modulated during follicle selection and in response to the increase in circulating LH level. The comparison of computerized protein patterns of mare follicular fluids 


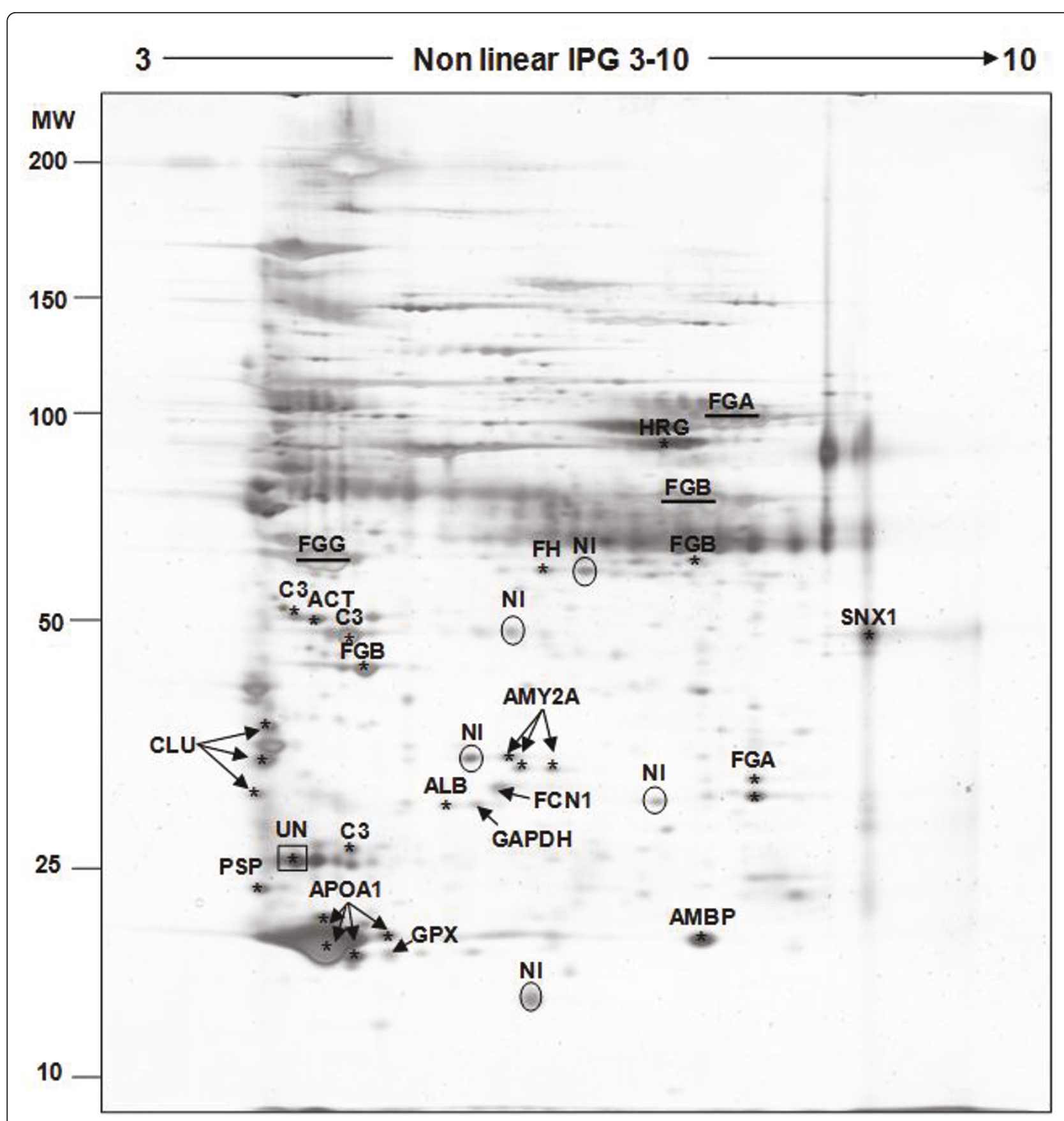

Figure 5 Identification of proteins from enriched mare follicular fluid by hexapeptide ligand library column. $100 \mu \mathrm{g}$ of proteins were applied to a non-linear IPG strip (pl 3-10) in the first dimension and separated on SDS-PAGE (10\%) (Molecular Weight: 10-200 kDa range). All identified proteins are named on the figure and their characteristics are shown in Table 3. NI: Not-Identified proteins.

collected at different physiological stages revealed no differentially expressed proteins. In fact, the 2D proteins patterns were almost similar among groups, and the high-abundance proteins, were observed as dominant intense spots on the 2D-PAGE. This result was in accordance with an earlier study in which no difference was observed in protein patterns of human follicular fluid derived from mature and immature follicles [5]. One hypothesis could be that during follicle growth and development, the follicular cell layers become more vascularized and permeable to serum proteins. As a consequence, serum proteins may pass thought the basal lamina and enter into the follicle antrum. These proteins are present at high concentration in the follicular 
Table 3 Identified proteins of mare follicular fluid after enrichment by hexapeptide ligand library and separation by 2D-PAGE (pl: 3-10; MW: 10-200; silver staining)

\begin{tabular}{|c|c|c|c|c|c|c|c|}
\hline \multirow[t]{2}{*}{ Gene } & \multirow{2}{*}{$\begin{array}{c}\text { Accession } \\
\mathrm{N}^{0} 1\end{array}$} & \multirow[t]{2}{*}{ Protein name } & \multirow[t]{2}{*}{ Score $^{2}$} & \multicolumn{2}{|c|}{ Theoretical } & \multirow[t]{2}{*}{ Peptide $\mathrm{N}^{\circ 3}$} & \multirow[t]{2}{*}{ Sequence coverage (\%) ${ }^{4}$} \\
\hline & & & & $\mathrm{pl}^{3}$ & $\mathrm{Mr}(\mathrm{Da})^{3}$ & & \\
\hline$\overline{A C T}$ & gi|6626 & Actin & 55 & 5.29 & 41779 & 1 & 2 \\
\hline ALB & gi|126723507 & Preproalbumin & 188 & 5.95 & 68554 & 4 & 7 \\
\hline ALB & gi|2492797 & Albumin precursor & 28 & 5.85 & 67837 & 1 & 1 \\
\hline AMBP & gi|149738520 & AMBP protein precursor & 101 & 6.82 & 38985 & 2 & 5 \\
\hline AMY2A & gi|178585 & Alpha-amylase & 78 & 6.32 & 57714 & 1 & 3 \\
\hline AMY2A & gi|178585 & Alpha-amylase & 37 & 6.32 & 57714 & 1 & 3 \\
\hline AMY2A & gi|178585 & Alpha-amylase & 106 & 6.32 & 57714 & 1 & 3 \\
\hline APOA1 & gi|149716548 & Apolipoprotein A-I precursor & 883 & 5.66 & 30312 & 13 & 50 \\
\hline APOA1 & gi|149716548 & Apolipoprotein A-I precursor & 675 & 5.66 & 30312 & 13 & 44 \\
\hline APOA1 & gi|149716548 & Apolipoprotein A-I precursor & 900 & 5.66 & 30312 & 17 & 62 \\
\hline APOA1 & gi|149716548 & Apolipoprotein A-I precursor & 281 & 5.66 & 30312 & 6 & 25 \\
\hline $\mathrm{C} 3$ & gi|73987236 & Complement C3 precursor & 85 & 6.95 & 173988 & 1 & 1 \\
\hline C3 & gi|116597 & Complement C3 precursor & 53 & 6.12 & 186342 & 1 & 0 \\
\hline C3 & gi|554423 & Complement component C3 & 179 & 5.73 & 31844 & 3 & 17 \\
\hline C3 & gi|554423 & Complement component C3 & 86 & 5.73 & 31844 & 2 & 8 \\
\hline CLU & gi|126352584 & Clusterin & 43 & 5.77 & 52121 & 1 & 2 \\
\hline CLU & gi|126352584 & Clusterin & 248 & 5.77 & 52121 & 3 & 12 \\
\hline CLU & gi|126352584 & Clusterin & 240 & 5.77 & 52121 & 4 & 12 \\
\hline FCN1 & gi|194226003 & Ficolin 1 & 156 & 5.37 & 34486 & 4 & 14 \\
\hline FGA & gi|3789960 & Fibrinogen A-alpha chain & 65 & 6.45 & 49477 & 1 & 2 \\
\hline FGA & gi|3789960 & Fibrinogen A-alpha chain & 65 & 6.45 & 49477 & 2 & 4 \\
\hline FGA & gi|3789960 & Fibrinogen A-alpha chain & 695 & 6.45 & 49477 & 10 & 37 \\
\hline FGB & gi|149698358 & Fibrinogen beta chain precursor & 502 & 8.53 & 55398 & 6 & 26 \\
\hline FGB & gi|149698358 & Fibrinogen beta chain precursor & 409 & 8.53 & 55398 & 8 & 28 \\
\hline FGB & gi|149698358 & Fibrinogen beta chain precursor & 137 & 8.53 & 55398 & 2 & 6 \\
\hline FGB & gi|149698358 & Fibrinogen beta chain precursor & 125 & 8.53 & 55398 & 2 & 6 \\
\hline FGG & gi|1916266 & Fibrinogen-gamma & 69 & 4.78 & 8740 & 2 & 62 \\
\hline $\mathrm{FH}$ & gi|194227377 & Complement regulator factor $\mathrm{H}$ & 95 & 7.52 & 140649 & 2 & 1 \\
\hline GAPDH & gi|31645 & Glyceraldehyde-3-phosphate dehydrogenase & 38 & 8.26 & 36031 & 1 & 4 \\
\hline GPX & gi|7262515 & glutathione peroxidase & 144 & 5.78 & 8893 & 2 & 37 \\
\hline HRG & gi|194222677 & Histidine-rich glycoprotein & 227 & 7.64 & 43003 & 4 & 12 \\
\hline PSP & gi|126352355 & Parotid secretory protein & 79 & 4.75 & 26882 & 2 & 9 \\
\hline SNX1 & gi|1497111176 & Nexin-1 isoform 1 & 75 & 9.53 & 44065 & 1 & 3 \\
\hline UN & gi|28317 & Unnamed protein product & 84 & 5.17 & 59492 & 1 & 2 \\
\hline
\end{tabular}

${ }^{1}$ Accession $\mathrm{N}^{\circ}$ is an accession number from the NCBInr databases. ${ }^{2}$ Score is $-10^{*}$ Log $(\mathrm{P})$, where $\mathrm{P}$ is the probability that the observed match is a random event, it is based on NCBInr database using the MASCOT searching program. ${ }^{3}$ PI: isoelectric point; Mr: Molecular weight; Peptid No: Peptid number ${ }^{4}$ Sequence coverage (\%) is based on number of peptide masses matched in NCBInr databases.

fluid, and can mask the less abundant proteins that are locally produced by follicle cells.

In order to identify some proteins produced locally by follicular cells, we also compared the 2D-PAGE patterns of crude follicular fluid with matching serum samples. Thirty differential proteins spots were observed, from which one spot was present only in follicular fluid whereas eight were found only in serum. The reason why some proteins are absent from follicular fluid could be due to either their degradation in follicular fluid or their inability to pass through the blood-follicle barrier and to enter into the antrum. In addition, 21 spots were downregulated in follicular fluid in comparison to serum (e.g. alpha-2-macroglobulin, ceruloplasmin and antithrombinIII). All of these proteins are produced by the liver and belong to the acute phase proteins family. Nevertheless, de novo expression of $\alpha 2$-macroglubulin by granulosa cells has been previously demonstrated [23,24]. Furthermore, antithrombin-III is necessary to block the coagulation process in follicular fluid and to maintain the fluidity of follicular fluid until the release of the oocyte at ovulation [25]. 


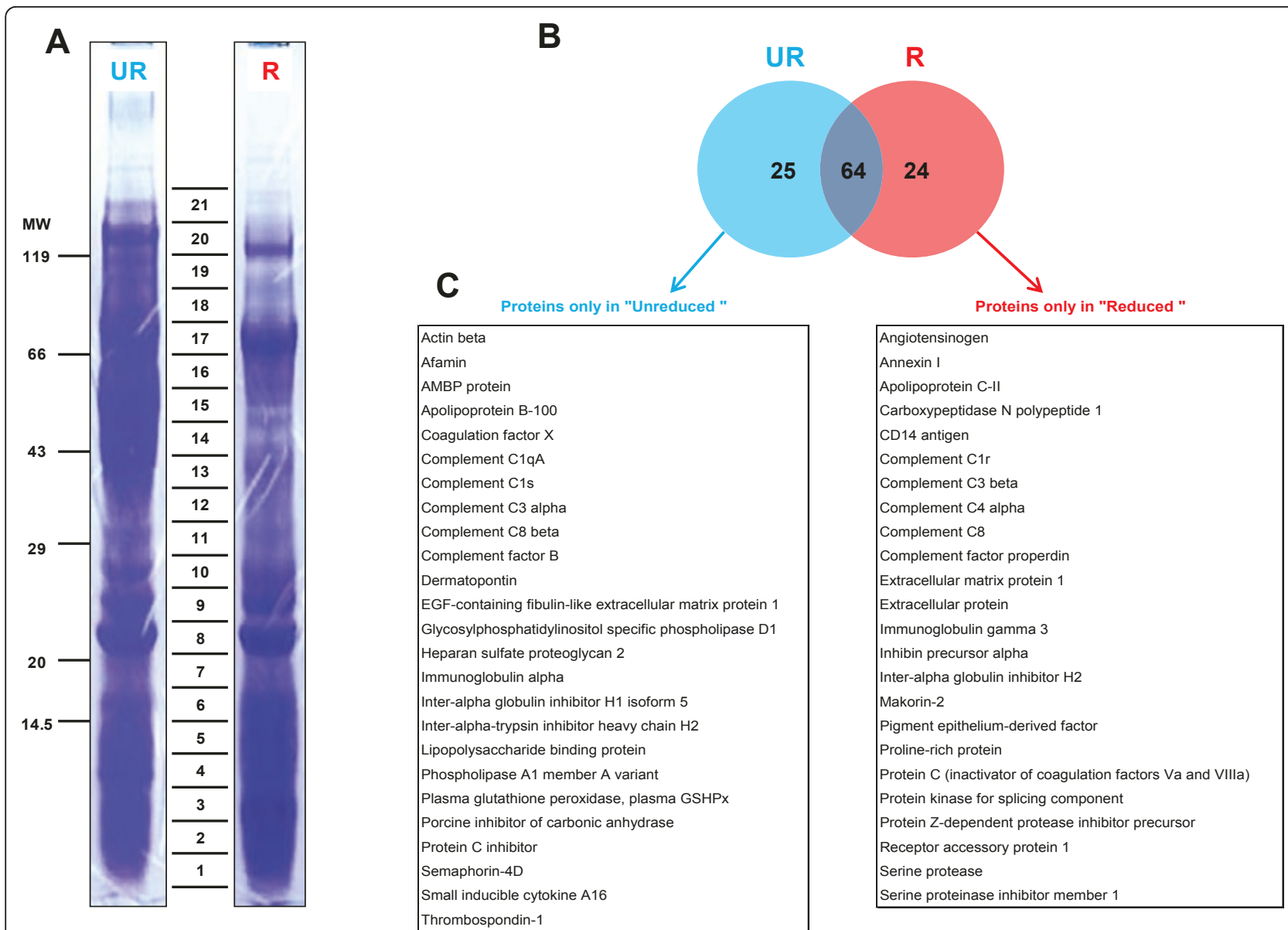

Figure 6 1D-PAGE separation of mare follicular fluid proteins after enrichment by hexapeptide ligand library column under unreduced (UR) and reduced (R) conditions. (A) 21 bands were cut in each lane from 1D-PAGE (CBB staining) and the proteins were identified by mass spectrometry. The result of identification is summarized in Additional file 3 for reduced conditions and Additional file 4 for unreduced conditions. (B) Venn diagram highlights the non-overlapping and common proteins identified in both conditions. (C) Tables show the list of non-overlapping proteins in each condition (alphabetical order).

\section{Immunodepletion/enrichment of mare follicular fluid prior to proteomic analysis}

Almost all of identified proteins belonged to high-abundance serum proteins. We hypothesized that the depletion of such proteins may improve the resolution and the detection of low-abundance proteins. To our knowledge, no method had yet been developed to deplete the follicular fluid protein composition prior to its proteomic analysis. For this purpose, we compared the efficiency of four Immunodepletion columns known to be effective in filtering out some high-abundance proteins from human serum. These columns were based on either IgY (ProteomeLab IgY-HSA and ProteomeLab IgY-12) or on IgG (MARS-6 and ProteoPrep 20) [26-29]. Despite the similarity between these two types of antibodies, there exist some differences in their chemical structures [30]. According to our results of protein assays and 2D-PAGE, IgY columns demonstrated a higher depletion efficiency than IgG columns.
This could be explained by the fact that IgY antibodies are less species-specific than IgG, and thus display a higher binding capacity to bind mare proteins. Moreover, we showed that ProteomeLab IgY-HAS and Mars- 6 were more efficacious in removing albumin and immunoglobulins from mare follicular fluid than the two other columns. Nevertheless, the decrease of albumin in depleted fractions failed to reveal any new protein spot on 2D-PAGE patterns. This result was in accordance with the study by Echan et al. (2005) showing that 2D-PAGE analysis of depleted human plasma by MARS- 6 failed to reveal any low-abundance protein [31].

In order to identify some proteins after depletion by MARS-6 column, 18 protein spots were excised from 2DPAGE. From that number, 14 were identified positively which correspond to 12 unique proteins. All of these proteins except one were initially identified in crude mare follicular fluid and belong to high-abundance proteins. Of 


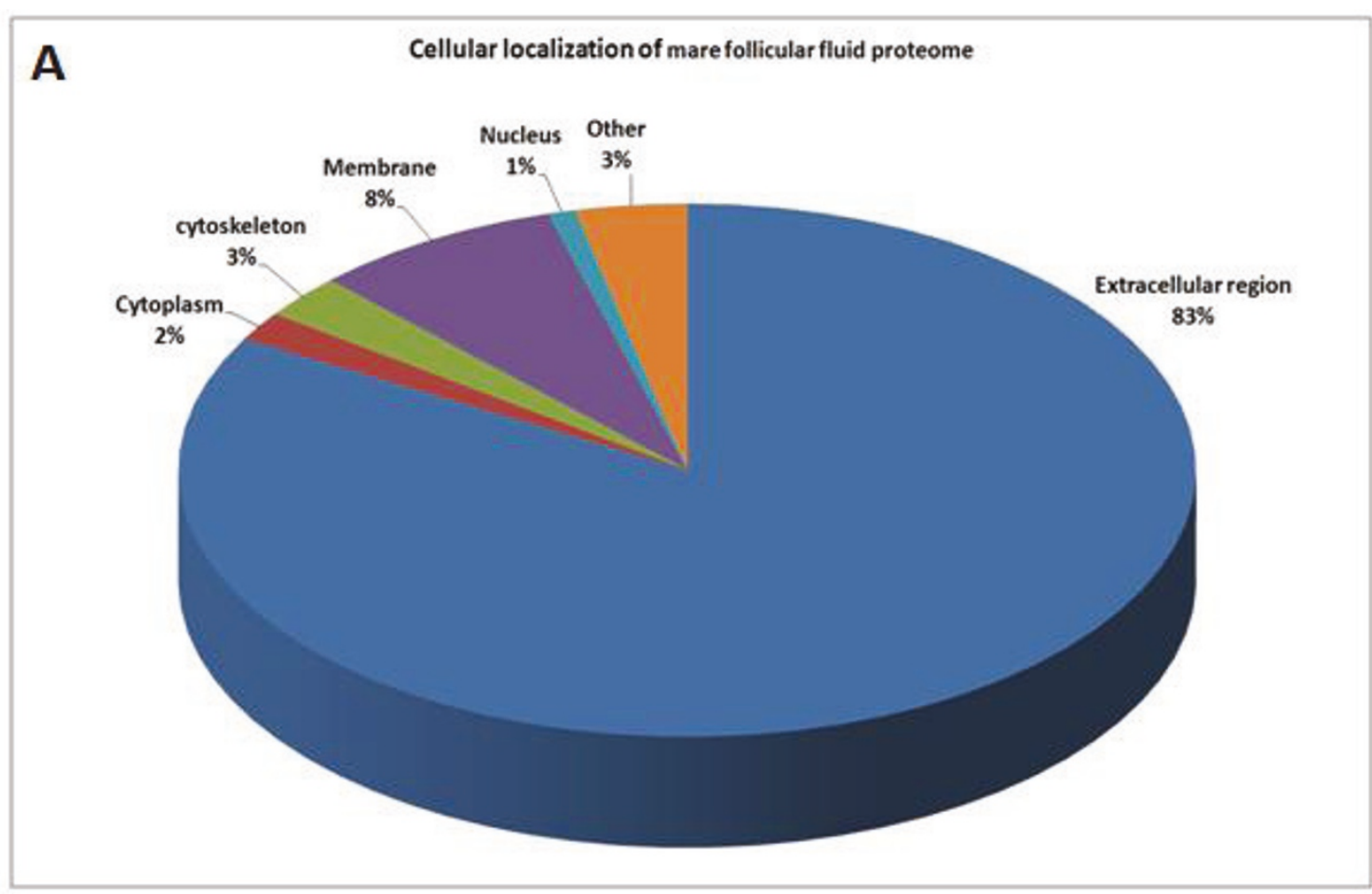

\section{B}

Functional classification of mare follicular fluid proteome

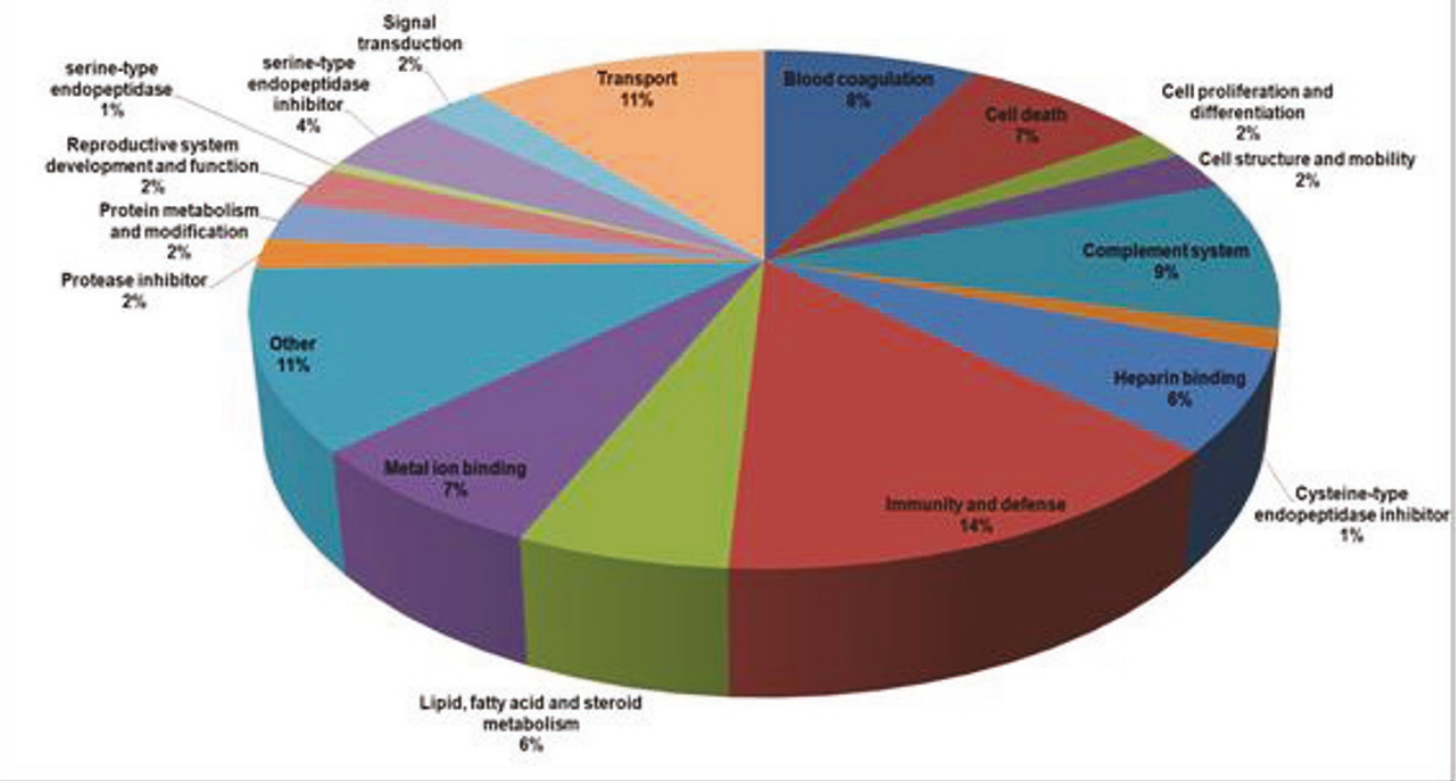

Figure 7 Annotation of mare follicular fluid proteome. (A) Subcellular localization and (B) functional classification of all proteins identified in mare follicular fluid.

note that histidine-rich glycoprotein was identified from an excised spot in the region initially occupied by albumin, which clearly confirmed the potential masking effect of albumin as a high-abundant protein.
Although the Immunodepletion strategy succeeded in removing selectively high-abundance serum proteins from various biological fluids $[29,32]$, it failed to deplete the mare follicular fluid under our experimental 
Table 4 Overview of studies performed on follicular fluid of four different species

\begin{tabular}{|c|c|c|c|c|}
\hline Study & Follicular fluid samples & Part of sample analyzed & Separation method & MS method \\
\hline This study & Mare (MFF) & $\begin{array}{l}\text { crude, depleted and enriched mare follicular } \\
\text { fluid from normal follicles }\end{array}$ & 2D-PAGE 1D-PAGE & nano-LC-MS/MS \\
\hline $\begin{array}{l}\text { Fahiminiya et al. } \\
\qquad(2010)\end{array}$ & Canine (CFF) & crude canine follicular fluid from normal follicles & 2D-PAGE & nano-LC-MS/MS \\
\hline $\begin{array}{l}\text { Angelucci et al. } \\
\qquad(2006)\end{array}$ & Human (HFF) & $\begin{array}{l}\text { crude follicular fluid from normo-ovulatory } \\
\text { women undergoing assisted reproduction } \\
\text { techniques due to a male infertility factor }\end{array}$ & 2D-PAGE & MALDI-TOF-MS \\
\hline $\begin{array}{l}\text { Jarkovska et al. } \\
\qquad(2010)\end{array}$ & Human (HFF) & $\begin{array}{l}\text { depleted follicular fluid of women undergoing } \\
\text { successful IVF }\end{array}$ & 2D-PAGE ProteomeLab PF 2D & MALDI-TOF-MS \\
\hline $\begin{array}{l}\text { Bijttebier et al. } \\
\text { (2009) }\end{array}$ & Porcine (PFF) & crude porcine follicular fluid of normal follicles & iTRAQ labeling & LC ESI-Q-TOF MS/MS \\
\hline
\end{tabular}

For each study the following information is presented: 1) follicular fluid derived from specific species 2) the nature of the samples, used in the study (physiological status and whether the study focused on depleted, enriched or crude follicular fluid) 3 ) the methods used to separate proteins and peptides and 4) MS method used for analysis.

conditions, since it did not increase the list of identified proteins. One major limitation of this approach is the dilution of proteins into high salt buffers, which may reach a 100 fold ratio compared to the original sample. Thus, additional handling steps of concentration are required. In our study, we were successful in using the recommended ultra-filtration technique to concentrate samples (protein recovery of about $75-85 \%$, data not shown). Nevertheless, this was time consuming procedure which may lead to the loss of some proteins. In our opinion, another limitation of the Immunodepletion strategy is related to potential interaction between some of high-abundance proteins and other factors, since the Immunodepletion steps have to be carried out under

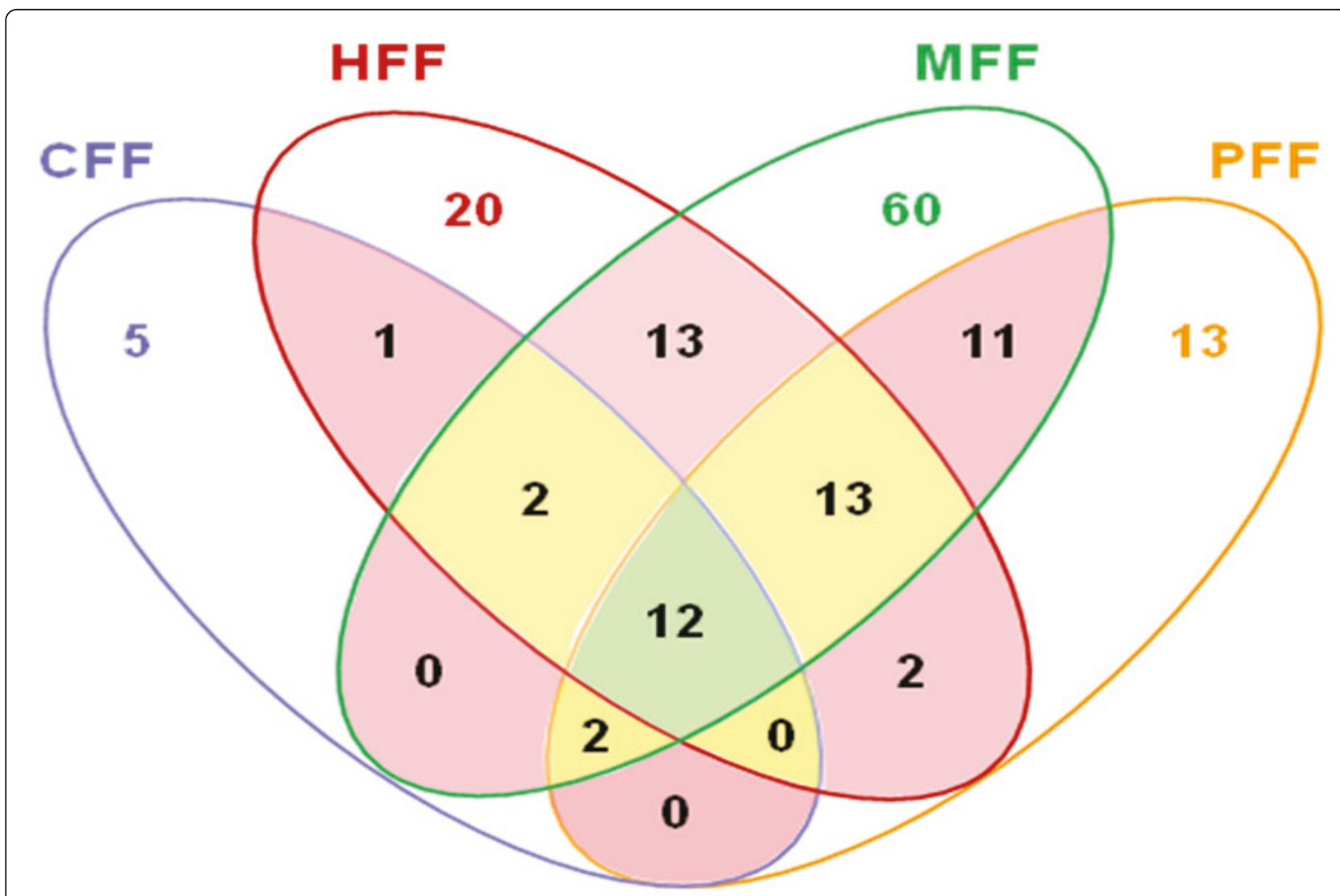

Figure 8 Overlap of identified proteins in follicular fluid of four different species. Green (12 proteins) and yellow (17 proteins) areas contains the proteins which are present in all or 3 out of 4 species (CFF: Canine, HFF: Human, MFF: Mare and PFF: Porcine Follicular Fluid), respectively. 
Table 5 The list of species specific proteins presented in Figure 8

\begin{tabular}{|c|c|}
\hline $\begin{array}{l}\text { Follicular } \\
\text { fluid }\end{array}$ & Proteins \\
\hline Canine (CFF) & ACT, HPR, HV01, HV02, AZGP1 \\
\hline Human (HFF) & $\begin{array}{l}\text { ALPPL2, ANXA4, CAT, EIF4E, SOD3, FCN3, GSTA2, GSTP1, GCHFR, HSPB1, IGFBP1, LMNA, LRG1, LDHB, NME1, PDIA3, APCS, TPI1, UCHL3, } \\
\text { ZNF229 }\end{array}$ \\
\hline Porcine (PFF) & ORM1, AFP, ANGPTL2, APOC3, Cd51, F9, COL7A1, CST7, gpr107, HBB, SERPIND1, ApoN, TGFBR2 \\
\hline Mare (MFF) & $\begin{array}{l}\text { ACTB, A1BG, ANXA1, APOB, APOC2, C4BPA, CESdD1, CPN1, CCL16, F10, F12, F13A1, C1QA, C1R, C5, C8A, C8G, CFP, CRISPLD2, DPT, } \\
\text { DNAH7, EFEMP1, ECM1, FETUB, FBLN1, FCN1, GPX3, GAPDH, HLA-B, IGHG3, IgG, IGHC1, IgG6, IgG7, INHA, INHBB, KNG1, LTF, LRRC15, } \\
\text { LBP, LYZL1, MFAP4, CD14, AMY2A, Psp, LCAT, GPLD1, PLA1A, SERPINF1, SERPING1, SERPINA5, MKRN2, Cdk12, SERPINA10, REEP1, } \\
\text { SEMA4D, HTRA1, SNX1, THBS1, PROC }\end{array}$ \\
\hline
\end{tabular}

non-denaturing conditions. Thus, the depletion of proteins like albumin may lead to the loss of many other compounds including some low-abundance proteins [33-36]. An additional step of protein-protein interactions dissociation during sample preparation should overcome this limitation.

In parallel with the Immunodepletion strategy, we also evaluated the efficiency of hexapeptide ligand library columns, always with the aim to increase the detection of low-abundance proteins by 2D-PAGE. This method is based on affinity chromatography, where the complex biological sample containing high and low-abundance proteins (here the follicular fluid) is exposed to a very large number of hexapeptide ligands [37]. Hexapeptide ligand library column enrich low-abundance proteins while concomitantly reducing the concentration of highabundance proteins [38], according to the principle of saturation-overloading chromatography. In addition, some high-abundance proteins like albumin and immunoglobulins are equalized, and not totally removed after enrichment.

In order to test the hypothesis that the hexapeptide ligand strategy may improve the detection of low-abundance proteins in mare follicular fluid, we excised 37 proteins from 2D-PAGE either by localization or by intensity. This led to identification of 33 spots corresponding to 18 proteins in enriched follicular fluid. In fact, three of these proteins (ALB, APOA1, and FGA) had already been identified in crude follicular fluid. Hexapeptide ligand library column allowed us to enlarge the list of the identified proteins from 18 in crude follicular fluid to 31 after enrichment. New identified proteins were either cytosolic (ACT, SNX1, GAPDH, GPX) or secretory (AMBP, FCN1, CLU, C3, FGG, FGB, FH and PSP). Of note is the fact that secretory proteins belong to the acute phase proteins family, and normally originate from serum. The role of cytosolic proteins like GAPDH and ACT is not clearly demonstrated in reproduction. We hypothesize that the presence of actin in follicular fluid could be related to changes in microfilaments and degradation of extracellular matrix during the preovulatory phase.
Ficolin-1 was demonstrated in mare follicular fluid, whereas ficolin-3 was previously identified in human follicular fluid [9]. This protein activates the complement factor and plays a role in the immune system. Furthermore, three proteins (Fibrinogen $\beta$, complement regulator factor $\mathrm{H}$ and $\mathrm{AMBP}$ ) were identified in the region initially occupied by heavy and light chains of immunoglobulins. Altogether, our study showed that the combination of hexapeptide ligand library column and 2D-PAGE led to an improvement in the resolution of 2D-PAGE since gels exhibit many more protein spots, in the entire $\mathrm{pH}$ interval, than with crude samples. In addition, new proteins were identified in follicular fluid after enrichment.

The shotgun approach used in this study revealed that 24 proteins were identified only in reduced conditions whereas 25 were identified only in unreduced conditions. The use of this approach in combination with hexapeptide ligand library column allowed us to increase the list from 31 to 113 unique proteins in mare follicular fluid. Again, some of them were high-abundance proteins whereas several may play a significant role during folliculogenesis. For example, afamin is a glycoprotein with vitamin E-binding properties may be involved in ovarian activity and function since vitamin $\mathrm{E}$ plays an important role in ovarian steroidogenesis [39]. More recently, Jackson et al. (2007) showed a significant decrease in total afamin concentration in serum of patients with ovarian cancer, compared to healthy controls [40]. This protein has already been identified in human follicular fluid [8]. Annexin-I (ANX1) was identified in this study whereas only annexin IV (ANX4) was previously reported in the human follicular fluid [8]. In addition, five various isoforms of annexin (ANX1, ANX 2, ANX4, ANX 5 and ANX 11) have already been identified in human ovary [41]. This protein is part of a group calcium/phospholipid-binding proteins involved in regulation, proliferation, exocytosis and membrane fusion [42]. Another group of proteins that we identified in the follicular fluid correspond to extracellular matrix proteins, which are known to play important roles in cell-matrix interactions, matrix assembly and wound healing [43]. Dermatopontin is a widely distributed small molecular weight protein, assumed to be involved in wound healing. One 
can hypothesize that the two latter proteins are functionally involved in the repair of the follicular wall after ovulation. Vitronectin has previously been demonstrated in bovine follicular fluid and its concentration varies with the stage of follicle development [18]. Although the role of this protein in ovarian follicular development is not known, it may play a role in follicular growth, selection of the dominant follicle and the ovulation process, due to interactions with other related glycoproteins (fibronectin, laminin, etc.).

In the present study, extracellular matrix protein 1 (ECM1) was also identified in the follicular fluid. ECM1 is a secretary glycoprotein suggested to play a role in angiogenesis [44]. The anticoagulant heparan sulfate proteoglycan has previously been found in rodent granulosa cells and in human follicular fluid. It probably plays a role in the rupture of the ovarian follicle at the time of ovulation [45]. Finally, glutathione peroxidase has already been shown in human follicular fluid [46,47] and has been suggested to protect the organism from oxidative damage.

\section{Annotation of all identified proteins in mare follicular fluid}

Finally, we carried out subcellular localization and molecular function classification of all the proteins identified in this study $(\mathrm{n}=113)$. We demonstrated that the majority (83\%) was localized at the extracellular region, which implies that these proteins either come from the circulation system or are secreted by the follicle cells. Surprisingly, the rest were localized in the intracellular position like cytoplasm, cytoskeleton, membrane or nucleus. This finding is entirely in keeping with the hypothesis that some of follicle cells are being damaged during follicle development, leading to the release of their cellular component into the follicular fluid. Some evidences suggest that the formation of follicle cavity may result from the death of granulosa cells. If so, follicular fluid may fill the space left with DNA providing the osmotic force [48]. In addition, the procedure of follicular fluid collection probably could lead to some cellular damage.

The functional annotation showed that the proteins identified in this study were involved in 18 groups of molecular functions. Most proteins were classified in immunity and defense (14\%), complement system (9\%) or blood coagulation (8\%) categories. All of these proteins are crucial components in inflammatory responses. Twelve proteins belong to the family of the complement factor with their inhibitors (factor I, Factor H). Recently, Jarkovska et al. (2010) showed the involvement of innate immune function of complement cascade proteins in human follicular fluid, and suggested a possible link to angiogenesis which is a vital process in folliculogenesis [9].
It is known that blood coagulation proteins are involved in both intrinsic (contact activation pathway) and extrinsic (tissue factor) pathways. Yamada et al. (1995) described only the intrinsic pathway proteins involvement in mare follicular fluid [49]. These proteins lead to fibrin formation and coagulation of follicular fluid. In the present study, we also identified inhibitors of coagulation, like antithrombin-III, which helps the follicular fluid to keep its fluidity during the transfer of the oocyte from the follicle to the oviduct.

Proteins involved in development and function of the reproductive system represent only $2 \%$ of our identified proteins. These were various fragments of inhibins (alpha and beta) and angiotensinogen. Inhibins are produced by granulosa cells in response to FSH stimulation that play a role in inhibiting FSH synthesis and secretion [50]. It has already been shown in follicular fluid of various species by using immune-detection or biological assays $[51,52]$ but its identification by a proteomic approach is unique, and shows the power of the methods we used in this study.

Angiotensinogen was classified as a protein involved in the development and function of the reproductive system. Besides the well-described role of angiotensinogen in the renin-angiotensin system (RAS) regulating vasopressor, electrolyte, and fluid homeostasis [53], increasing evidence suggested a role for angiotensinogen in embryonic development. This protein has already been identified in follicular fluid of human [8] and porcine [54], as well as in rat granulosa cells [55].

\section{Description of an overlapping mare follicular fluid protein set shared with three other mammalian species}

One may regard the follicular fluid proteome as made up of two parts: (1) a fixed set of proteins ("core proteome"), which composition does not vary, and which should be present in follicular fluid irrespective of species or/and the analytical methods used, and (2) a variable set of proteins, which abundance is dependent on several physiological and experimental factors. Taking this consideration, we compared our results with those from three previous comprehensive proteomic studies of the follicular fluid which have been performed in three different species including canine, human and porcine $[8,9,11,12]$. Using this comparison, the list of identified proteins in the follicular fluid is increased from 113 to 154. Twelve of them (ALB, AHSG, SERPINC1, APOA1, CLU, C4A, CFB, FGG, HP, RBP4, TF and GC) were identified in all studies, regardless of the species studied, whereas 17 other were present in at least three out of the four species studied. The list of species specific proteins $(\mathrm{MFF}=60$, $\mathrm{HFF}=20, \mathrm{PFF}=13$ and $\mathrm{CFF}=5$ ) showed that our proteomic method is more powerful to identify follicular 
fluid specific proteins. The closer look at these species specific proteins showed that some of them were different fragments of high-abundance proteins like immunoglobulins, complement factors and apolipoprotein, and this diversity could be due to various experimental procedures on the sample. In addition, the proteins related to reproduction (inhibins) were identified only after enrichment of mare follicular fluid. Furthermore, we found several new proteins in mare follicular fluid but their possible role in reproduction has not been investigated.

\section{Conclusions}

This study provides the first description of mare follicular fluid proteome during the late follicle development stages. Our result of protein identification showed that the majority of proteins are high-abundance proteins, previously identified in the serum. Although the comparison of the proteins profiles of follicular fluids collected at three physiological stages revealed no differential proteins, the comparison between follicular fluid and serum revealed 30 differentially expressed proteins. In addition, we showed that enrichment method was a powerful tool compared to Immunodepletion of follicular fluid before its proteomic analysis. Based on our results, we conclude that the enrichment method can be used in combination with 2D-PAGE and mass spectrometry to visualize and further identify the low-abundance proteins in follicular fluid.

\section{Methods}

Animals, monitoring of oestrous cycle and treatment Cyclic Welsh pony mares (3-19 years old, $\mathrm{n}=12)$ from our experimental herd (INRA, Nouzilly, France) were used in this study. They were in good body condition, kept indoors, fed with concentrates $(1.8 \mathrm{~kg} /$ mare/day $)$ and had free access to water and trace-mineralized salt. Ovarian activity was assessed by routine daily transrectal ultrasonic imaging. Mares were randomly divided into three groups (see collection of mare follicular fluid). Mares from the third group received an i.v. injection of crude equine gonadotropins (CEG; $15 \mathrm{mg}$ i.v.) when the largest follicle reached $33 \mathrm{~mm}$ in order to induce preovulatory maturation [56]. All procedures used for mare follicular fluid collection (this study) were approved by the agricultural and veterinary research agencies (approval number C37-175-2/37-035) and conducted in accordance with the guidelines for Care and Use of Agricultural Animals in Agricultural Research and Teaching.

\section{Collection of mare follicular fluid}

Follicular fluid samples were collected at three different follicle development stages. In the first group of mares, punctures were performed at the early dominance stage $(\mathrm{n}=3)$, when the largest follicle was between 22 and $25 \mathrm{~mm}$ in diameter. In the second group of mares, punctures were performed at the late dominant stage $(\mathrm{n}=3)$, when the largest follicle reached $33 \mathrm{~mm}$ in diameter. The third group of mares was punctured at the preovulatory stage $(\mathrm{n}=3), 34$ hours after CEG injection. Follicular fluid samples were aspirated by transvaginal ultrasound-guided follicular puncture with a $7.5 \mathrm{MHz}$ electronic convex transducer (Aloka SSD-900) equipped with a sterile single lumen needle $(60 \mathrm{~cm}$-long, $1.8 \mathrm{~mm}$ outer diameter), as previously described [56,57]. During each puncture session, blood samples were also collected from the jugular vein for serum preparation. Follicular fluids and serum were centrifuged for $10 \mathrm{~min}$ at $3000 \mathrm{~g}$ and individually frozen at $-80^{\circ} \mathrm{C}$ until further processing. Only follicular fluids free from blood contamination were kept for further analysis.

\section{Immunodepletion and enrichment of follicular fluids}

Four different human serum Immunodepletion columns were used to remove high-abundance proteins from mare follicular fluid. The names and properties of these columns are presented in Additional file 1. In addition, hexapeptide ligand library column (One-Step Elution) was also used to enrich crude mare follicular fluid [58]. Briefly, hexapeptide ligand library columns were washed two times (each $5 \mathrm{~min}$ ) with water, then with wash buffer. Thereafter, $1 \mathrm{ml}$ of crude FF was applied to each column and incubated for $2 \mathrm{~h}$. The columns were then washed 3 times (each $5 \mathrm{~min}$ ) with wash buffer. Finally, proteins bound to hexapeptides were eluted by $3 \times 100 \mu \mathrm{L}$ of elution reagent (enriched FF). All depletions and enrichment steps were performed at room temperature as recommended by the manufacturer.

\section{Protein assay and gel electrophoresis of mare follicular fluid and serum}

All chemicals and materials used for proteomic analysis were purchased from Bio-Rad (Marnes-la-Coquette, France), unless otherwise indicated.

\section{Protein assay}

The total protein content of crude, depleted and enriched mare follicular fluid samples was determined using BioRad DC (detergent compatible) assay with bovine serum albumin as standard (Pierce, Rockford, IL), and statistically analyzed by the non-parametric Kruskal-Wallis test. Before electrophoresis, the depleted and enriched fractions were concentrated by $10 \mathrm{kDa}$ molecular mass cut-off centrifugal concentrators (Microcon ${ }^{\circledR}$, Millipore, Bedford, MA, USA) and the $\mathrm{pH}$ of fractions was neutralized by $50 \mathrm{mM}$ Tris PH 8.8.

\section{D-PAGE}

Enriched fractions $(15 \mu \mathrm{l})$ of mare follicular fluid were diluted with an equal volume of buffer (Tris- $\mathrm{HCl} 160 \mathrm{mM}$ pH6.8, EDTA $10 \mathrm{mM}$, SDS 10\%, Glycerol 20\%, bromophenol blue) in reduced (with $\beta$-mercaptoethanol 10\%) and 
unreduced (without $\beta$-mercaptoethanol 10\%) conditions. The samples were boiled for $4 \mathrm{~min}$ before being loaded into each lane. Proteins were separated using the NuPage system (Invitrogen, Cergy Pontoise, France) with 4-12\% Bis-Tris gels. Molecular weight standards were also routinely loaded. Electrophoresis was performed at a constant intensity of $200 \mathrm{~V}$. At the end of migration, gels were stained with $0.2 \%$ Coomassie Brilliant blue (CBB) (R350). In both conditions (reduced/unreduced), lanes were cut in 21 bands and processed for protein identification by mass spectrometry.

\section{D-PAGE}

The 2D-PAGE analysis was performed as previously published by Fahiminiya et al. (2010) [11,58]. Briefly, $100 \mu \mathrm{g}$ protein samples were diluted with hydration solution containing urea $(8 \mathrm{M})$, thiouree (2 M), CHAPS $(4 \% \mathrm{w} / \mathrm{v})$, ampholytes $(0.2 \%)$ and dithiothreitol (DTT, 20 $\mathrm{Mm}$ ), for isoelectric focussing (IEF). This solution was actively absorbed $\left(50 \mathrm{~V}, 20^{\circ} \mathrm{C}, 11-16 \mathrm{~h}\right)$ into Ready-

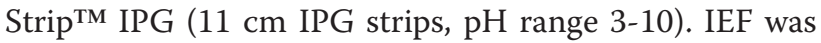
performed in Protean Isoelectric Focusing System using the following conditions: $400 \mathrm{~V}$ for $4 \mathrm{~h}, 4000 \mathrm{~V}$ for 13 $\mathrm{h}$, and $500 \mathrm{~V}$ for $14 \mathrm{~h}$. Before carrying out second dimensional SDS-PAGE, the strips were equilibrated twice, each time for $15 \mathrm{~min}$, with equilibration buffer (50 mM Tris- $\mathrm{HCl}$ pH 6.8 containing urea $(6 \mathrm{M})$, glycerol $(20 \% \mathrm{v} / \mathrm{v})$, SDS $(2 \% \mathrm{w} / \mathrm{v}))$. During two steps of equilibration, first DTT (2\%), then, iodoacetamide $(2.5 \%$ w/v) was added to equilibration buffer. Equilibrated IPG strips were subjected to SDS-PAGE (10\%). Gels were placed on running buffer containing $(0.25 \mathrm{M})$ Tris Base, (2 M), glycine and (1\%) SDS and was conducted as follows: $10 \mathrm{~mA} /$ gel for $45 \mathrm{~min}$ and $200 \mathrm{~V}$ for 5-6 h. After electrophoresis step, 2D-PAGE gels were stained with a mass spectrometry (MS) compatible silver nitrate. Three 2D gels were performed for each group.

\section{D-PAGE image analysis}

Stained gels were scanned and digitalized at 16-bit resolution using ImageScanner (Amersham Pharmacia Biotech, GE Healthcare Europe GmBH, Orsay, France). The resulting TIFF images were analyzed with Progenesis software (version 2008; Nonlinear Dynamics Ltd, Newcastle upon Tyne, UK), as previously described [58]. Using Progenesis, the automatic analysis protocol for gel images included spot detection, warping, background subtraction, average gel creation, matching, and reference gel modification. Each spot volume was normalized by volume per area ratio. Differentially expressed protein spots were determined using analysis of variance (ANOVA) which was included in the Progenesis software. The protein spots with a p-value less than 0.05 were considered as significant and those spots were subsequently cut from 2D gels and identified through mass spectrometry (MS).

\section{Identification of proteins by mass spectrometry}

Spots and bands of interest were cut into small blocks. Gel blocks were rinsed with water and acetonitrile before being reduced with dithiothreitol (DTT) and alkylated with iodoacetamide. They were incubated overnight at $37^{\circ} \mathrm{C}$ in $25 \mathrm{mM} \mathrm{NH} 4 \mathrm{HCO} 3$ with $12.5 \mathrm{ng} / \mu \mathrm{l}(\mathrm{CBB})$ or $6.25 \mathrm{ng} / \mu \mathrm{l}$ (silver) (Sequencing Grade, Roche, Paris) as described by Shevchenko et al. (1996) [59]. The tryptic fragments were extracted, dried, reconstituted with $0.1 \%$ formic acid, and sonicated for $10 \mathrm{~min}$. Nanoscale capillary liquid chromatography-tandem mass spectrometry (LC-MS/MS) using Q-TOF mass spectrometers was used to sequence the tryptic fragments as previously published by Belleannee et al. (2011) [60].

The peptide and fragment masses obtained were matched automatically to proteins in non-redundant database (NCBI all taxa) using the MS/MS ion search option of the MASCOT software http://www.matrixscience.com. For the database search, 2 tryptic missed cleavages were allowed and carbamidomethylcysteine and methionin sulfoxide were set as a variable modifications. The mass tolerance was $0.3 \mathrm{Da}$ for both precursors and fragment ions. Protein hits were validated if the protein scores were above the MASCOT default significance threshold $(\mathrm{p}<0.05)$.

\section{Functional and sub-cellular classification of mare follicular fluid proteins}

Functional classification of proteins was achieved using a multi-staged classification methodology based upon three different databases: 1) Gene Ontology http://www. geneontology.org 2) the "DAVID" database http://david. abcc.ncifcrf.gov and 3) UniProt http://www.uniprot.org. Proteins which remained unclassified after applying the three above mentioned tools were placed in the "not determined" (ND) category. Classification of proteins according to their cellular localization was achieved using UniProt and LOCATE Database http://locate.imb. uq.edu.au. Again, unclassified proteins were placed in the ND category.

\section{Additional material}

Additional file 1: Supplemental Table 1: Major Characteristics of the evaluated Immunodepletion columns.

Additional file 2: Supplemental Figure 1: Silver stained 2D-PAGE profile of depleted mare follicular fluid by four depletion columns: $100 \mu \mathrm{g}$ of proteins samples were applied to a non-linear IPG strip (pl 310) in the first dimension and separated on SDS-PAGE (10\%) gel in the second dimension (Molecular weight: 10-200 kDa range). The positions of some high-abundant proteins like albumin (ALB), immunoglobulin heavy chain $(\mathrm{IGHC} 1)$ and Apolipoprotein $A-I$ (APOA1) are shown on the Figure.

Additional file 3: Supplemental Table 2: The list of identified mare follicular fluid protein under reduced condition after enrichment with hexapeptide ligand library column. 
Additional file 4: Supplemental Table 3: The list of identified mare follicular fluid protein under unreduced condition after enrichment with hexapeptide ligand library column.

Additional file 5: Supplemental Table 4: Classification of all identified proteins in mare follicular fluid using diverse proteomic approaches.

Additional file 6: Supplemental Table 5: Overview of all identified proteins in follicular fluid of four different species using diverse proteomic approaches.

\section{Acknowledgements}

The authors wish to thank the staff of the experimental stud farm for technical assistance during mare ovarian punctures. The authors express their gratitude to Dr. Sylvain Lehmann for accepting us in his laboratory during the testing of depletion columns. Thanks to Marc Chodkiewicz for English corrections of the manuscript. This research program was financially supported by the French National Institute for Agricultural Research (INRA) and "Les Haras Nationaux" in France. Somayyeh Fahiminiya was a PhD student supported by a fellowship from INRA.

\section{Author details}

'INRA, UMR 6175 Physiologie de la Reproduction et des Comportements, F37380 Nouzilly, France. ${ }^{2}$ CNRS, UMR 6175 Physiologie de la Reproduction et des Comportements, F-37380 Nouzilly, France. ${ }^{3}$ Université François Rabelais de Tours, UMR 6175 Physiologie de la Reproduction et des Comportements, F-37041 Tours, France. ${ }^{4}$ Haras Nationaux, UMR 6175 Physiologie de la Reproduction et des Comportements, F-37380 Nouzilly, France. ${ }^{5}$ INRA, UMR 6175 Plate-forme d'Analyse Intégrative des Biomarqueurs, Laboratoire de Spectrométrie de Masse, F- 37380 Nouzilly, France. ${ }^{6}$ Institut de Génétique humaine du CNRS, UPR1142, 34396 Montpellier, France. ${ }^{7}$ Plateforme de Protéomique Clinique, Hôpital Saint Eloi - Biochimie, 34295 Montpellier, France.

\section{Authors' contributions}

SF was involved in the design of the study and performed sample collections, depletion, enrichment and the 2D-PAGE experiments on mare follicular fluid. She also computerized image analysis, analyzed the mass spectrometry data, performed bioinformatic analysis and drafted the manuscript. VL identified proteins by mass spectrometry. SR was provided the depletion columns and helped for Immunodepletion of follicular fluid. JLD assist to design the study and helped for follicular fluid enrichment. NG design and supervised the study, performed sample collection and depletion of follicular fluids, and revise the manuscript. All authors read and approved the final manuscript.

\section{Competing interests}

The authors declare that they have no competing interests.

Received: 31 May 2011 Accepted: 17 September 2011

Published: 17 September 2011

\section{References}

1. Gosden RG, Hunter RH, Telfer E, Torrance C, Brown N: Physiological factors underlying the formation of ovarian follicular fluid. J Reprod Fertil 1988, 82:813-825.

2. Fortune JE, Rivera GM, Yang MY: Follicular development: the role of the follicular microenvironment in selection of the dominant follicle. Anim Reprod Sci 2004, 82-83:109-126.

3. Richards JS: Hormonal control of gene expression in the ovary. Endocr Rev 1994, 15:725-751.

4. Veenstra TD, Conrads TP, Hood BL, Avellino AM, Ellenbogen RG, Morrison RS: Biomarkers: mining the biofluid proteome. Mol Cell Proteomics 2005, 4:409-418.

5. Spitzer D, Murach KF, Lottspeich F, Staudach A, Illmensee K: Different protein patterns derived from follicular fluid of mature and immature human follicles. Hum Reprod 1996, 11:798-807.
6. Anahory T, Dechaud H, Bennes R, Marin P, Lamb NJ, Laoudj D: Identification of new proteins in follicular fluid of mature human follicles. Electrophoresis 2002, 23:1197-1202.

7. Lee HC, Lee SW, Lee KW, Cha KY, Kim KH, Lee S: Identification of new proteins in follicular fluid from mature human follicles by direct sample rehydration method of two-dimensional polyacrylamide gel electrophoresis. J Korean Med Sci 2005, 20:456-460.

8. Angelucci S, Ciavardelli D, Di Giuseppe F, Eleuterio E, Sulpizio M, Tiboni GM, Giampietro F, Palumbo P, Di llio C: Proteome analysis of human follicular fluid. Biochim Biophys Acta 2006, 1764:1775-1785.

9. Jarkovska K, Martinkova J, Liskova L, Halada P, Moos J, Rezabek K, Gadher SJ, Kovarova H: Proteome mining of human follicular fluid reveals a crucial role of complement cascade and key biological pathways in women undergoing in vitro fertilization. J Proteome Res 2010, 9:1289-1301.

10. Mortarino M, Vigo D, Maffeo G, Ronchi S: Two-dimensional polyacrylamide gel electrophoresis map of bovine ovarian fluid proteins. Electrophoresis 1999, 20:866-869.

11. Fahiminiya S, Reynaud K, Labas V, Batard S, Chastant-Maillard S, Gerard N: Steroid hormones content and proteomic analysis of canine follicular fluid during the preovulatory period. Reprod Biol Endocrinol 2010, 8:132.

12. Bijttebier J, Tilleman K, Dhaenens M, Deforce D, Van Soom A, Maes D: Comparative proteome analysis of porcine follicular fluid and serum reveals that excessive alpha(2)-macroglobulin in serum hampers successful expansion of cumulus-oocyte complexes. Proteomics 2009, 9:4554-4565

13. Whitmore HL, Wentworth $\mathrm{BC}$, Ginther OJ: Circulating concentrations of luteinizing hormone during estrous cycle of mares as determined by radioimmunoassay. Am J Vet Res 1973, 34:631-636.

14. Irvine $\mathrm{CH}$, Alexander SL: The dynamics of gonadotrophin-releasing hormone, $\mathrm{LH}$ and FSH secretion during the spontaneous ovulatory surge of the mare as revealed by intensive sampling of pituitary venous blood. J Endocrinol 1994, 140:283-295.

15. Squires EL: Maturation and fertilization of equine oocytes. Vet Clin North Am Equine Pract 1996, 12:31-45.

16. Cabrera VO, Andino NV, Mateo De Acosta O: Protein electrophoretic patterns of bovine and porcine ovarian follicular fluid. J Endocrinol Invest 1985, 8:489-493.

17. Christiane $Y$, Demoulin A, Gillain D, Leroy F, Lambotte R, Lapiere CM, Nusgens B, Foidart JM: Laminin and type III procollagen peptide in human preovulatory follicular fluid. Fertil Steril 1988, 50:48-51.

18. Peter AT, Perrone MS, Asem EK: Bovine ovarian follicular fluid vitronectin content is influenced by the follicle size. Theriogenology 1995, 43:1239-1247.

19. Hirsch B, Leonhardt S, Jarry H, Reich $R$, Tsafriri A, Wuttke W: In vivo measurement of rat ovarian collagenolytic activities. Endocrinology 1993, 133:2761-2765.

20. Tadakuma H, Okamura H, Kitaoka M, Iyama K, Usuku G: Association of immunolocalization of matrix metalloproteinase 1 with ovulation in hCG-treated rabbit ovary. J Reprod Fertil 1993, 98:503-508.

21. Curry TE Jr, Sanders SL, Pedigo NG, Estes RS, Wilson EA, Vernon MW: Identification and characterization of metalloproteinase inhibitor activity in human ovarian follicular fluid. Endocrinology 1988, 123:1611-1618.

22. Jones $P B$, Muse KN, Wilson EA, Curry TE Jr: Expression of plasminogen activator (PA) and a PA inhibitor in human granulosa cells from preovulatory follicles. J Clin Endocrinol Metab 1988, 67:857-860.

23. Briggs DA, Sharp DJ, Miller D, Gosden RG: Transferrin in the developing ovarian follicle: evidence for de-novo expression by granulosa cells. Mol Hum Reprod 1999, 5:1107-1114.

24. Gaddy-Kurten D, Hickey GJ, Fey GH, Gauldie J, Richards JS: Hormonal regulation and tissue-specific localization of alpha 2-macroglobulin in rat ovarian follicles and corpora lutea. Endocrinology 1989, 125:2985-2995.

25. Shimada H, Kasakura S, Shiotani M, Nakamura K, Ikeuchi M, Hoshino T, Komatsu T, Ihara Y, Sohma M, Maeda Y, et al: Hypocoagulable state of human preovulatory ovarian follicular fluid: role of sulfated proteoglycan and tissue factor pathway inhibitor in the fluid. Biol Reprod 2001, 64:1739-1745

26. Martosella J, Zolotarjova N, Liu H, Nicol G, Boyes BE: Reversed-phase highperformance liquid chromatographic prefractionation of immunodepleted human serum proteins to enhance mass spectrometry 
identification of lower-abundant proteins. J Proteome Res 2005, 4:1522-1537.

27. Huang L, Harvie G, Feitelson JS, Gramatikoff K, Herold DA, Allen DL, Amunngama R, Hagler RA, Pisano MR, Zhang WW, Fang X: Immunoaffinity separation of plasma proteins by IgY microbeads: meeting the needs of proteomic sample preparation and analysis. Proteomics 2005, 5:3314-3328.

28. Zhang $W W$ : The use of gene-specific IgY antibodies for drug target discovery. Drug Discov Today 2003, 8:364-371.

29. Linke T, Doraiswamy S, Harrison EH: Rat plasma proteomics: effects of abundant protein depletion on proteomic analysis. J Chromatogr B Analyt Technol Biomed Life Sci 2007, 849:273-281.

30. Fang X, Zhang WW: Affinity separation and enrichment methods in proteomic analysis. J Proteomics 2008, 71:284-303.

31. Echan LA, Tang HY, Ali-Khan N, Lee K, Speicher DW: Depletion of multiple high-abundance proteins improves protein profiling capacities of human serum and plasma. Proteomics 2005, 5:3292-3303.

32. Dekker $L$, Bosman J, Burgers PC, van Rijswijk A, Freije R, Luider T, Bischoff R: Depletion of high-abundance proteins from serum by immunoaffinity chromatography: a MALDI-FT-MS study. J Chromatogr B Analyt Technol Biomed Life Sci 2007, 847:65-69.

33. Kragh-Hansen U: Structure and ligand binding properties of human serum albumin. Dan Med Bull 1990, 37:57-84.

34. Curry S, Brick P, Franks NP: Fatty acid binding to human serum albumin: new insights from crystallographic studies. Biochim Biophys Acta 1999, 1441:131-140.

35. Romeu AM, Martino EE, Stoppani AO: Structural requirements for steroid binding and quenching of albumin fluorescence in bovine plasma albumin. Biochim Biophys Acta 1976, 439:175-193.

36. Varshney A, Sen P, Ahmad E, Rehan M, Subbarao N, Khan RH: Ligand binding strategies of human serum albumin: How can the cargo be utilized? Chirality 2009, 22:77-87.

37. Righetti PG, Boschetti E, Lomas L, Citterio A: Protein Equalizer Technology: the quest for a "democratic proteome". Proteomics 2006, 6:3980-3992.

38. Guerrier L, Righetti PG, Boschetti E: Reduction of dynamic protein concentration range of biological extracts for the discovery of lowabundance proteins by means of hexapeptide ligand library. Nat Protoc 2008, 3:883-890.

39. Aten RF, Kolodecik TR, Behrman HR: Ovarian vitamin E accumulation: evidence for a role of lipoproteins. Endocrinology 1994, 135:533-539.

40. Jackson D, Craven RA, Hutson RC, Graze I, Lueth P, Tonge RP, Hartley JL, Nickson JA, Rayner SJ, Johnston C, et al: Proteomic profiling identifies afamin as a potential biomarker for ovarian cancer. Clin Cancer Res 2007, 13:7370-7379

41. Wang L, Zhu YF, Guo XJ, Huo R, Ma X, Lin M, Zhou ZM, Sha JH: A twodimensional electrophoresis reference map of human ovary. J Mol Med 2005, 83:812-821.

42. Kaetzel MA, Hazarika P, Dedman JR: Differential tissue expression of three 35-kDa annexin calcium-dependent phospholipid-binding proteins. J Biol Chem 1989, 264:14463-14470.

43. Okamoto O, Fujiwara S: Dermatopontin, a novel player in the biology of the extracellular matrix. Connect Tissue Res 2006, 47:177-189.

44. Sercu S, Zhang L, Merregaert J: The extracellular matrix protein 1: its molecular interaction and implication in tumor progression. Cancer Invest 2008, 26:375-384.

45. de Agostini Al, Dong JC, de Vantery Arrighi C, Ramus MA, Dentand-Quadri I, Thalmann S, Ventura P, Ibecheole V, Monge F, Fischer AM, et al: Human follicular fluid heparan sulfate contains abundant 3-O-sulfated chains with anticoagulant activity. J Biol Chem 2008, 283:28115-28124.

46. Luciano AM, Goudet G, Perazzoli F, Lahuec C, Gerard N: Glutathione content and glutathione peroxidase expression in in vivo and in vitro matured equine oocytes. Mol Reprod Dev 2006, 73:658-666.

47. Carbone MC, Tatone C, Delle Monache S, Marci R, Caserta D, Colonna R, Amicarelli F: Antioxidant enzymatic defences in human follicular fluid: characterization and age-dependent changes. Mol Hum Reprod 2003, 9:639-643.

48. Rodgers RJ, Irving-Rodgers HF: Formation of the ovarian follicular antrum and follicular fluid. Biol Reprod 2010, 82:1021-1029.

49. Yamada M, Gentry PA: The hemostatic profile of equine ovarian follicular fluid. Thromb Res 1995, 77:45-54.

50. Findlay JK: An update on the roles of inhibin, activin, and follistatin as local regulators of folliculogenesis. Biol Reprod 1993, 48:15-23.
51. Miller KF, Xie S, Pope WF: Immunoreactive inhibin in follicular fluid is related to meiotic stage of the oocyte during final maturation of the porcine follicle. Mol Reprod Dev 1991, 28:35-39.

52. Johnson PA, Brooks CF, Davis AJ: Pattern of secretion of immunoreactive inhibin/activin subunits by avian granulosa cells. Gen Comp Endocrinol 2005, 141:233-239.

53. Stroth $U$, Unger $T$ : The renin-angiotensin system and its receptors. $J$ Cardiovasc Pharmacol 1999, 33(Suppl 1):S21-28, discussion S41-23.

54. Miyata A, Ge $\sqcup$, Minamino N, Arimura A: Chemical characterization of angiotensin I in porcine follicular fluid. Peptides 1990, 11:117-121.

55. Thomas WG, Sernia C: The immunocytochemical localization of angiotensinogen in the rat ovary. Cell Tissue Res 1990, 261:367-373.

56. Duchamp G, Bour B, Combarnous Y, Palmer E: Alternative solutions to hCG induction of ovulation in the mare. J Reprod Fertil Suppl 1987, 35:221-228.

57. Okolski A, Bézard J, Duchamp G, Driancourt M, Goudet G, Palmer E: Successive puncture of the dominant follicle followed by ovulation and fertilization: a new experimental model for the study of follicular maturation in the mare. Biol Reprod 1995, 385-392, abst.

58. Fahiminiya S, Labas V, Dacheux J, Gerard N: Improvement of 2D-PAGE Resolution of Human, Porcine and Equine Follicular Fluid by Means of Hexapeptide Ligand Library. Reprod Domest Anim 2010.

59. Shevchenko A, Wilm M, Vorm O, Mann M: Mass spectrometric sequencing of proteins silver-stained polyacrylamide gels. Anal Chem 1996, 68:850-858.

60. Belleannee C, Labas V, Teixeira-Gomes AP, Gatti IL, Dacheux JL, Dacheux F: Identification of luminal and secreted proteins in bull epididymis. $J$ Proteomics 2011, 74:59-78.

doi:10.1186/1477-5956-9-54

Cite this article as: Fahiminiya et al.: Proteomic analysis of mare follicular fluid during late follicle development. Proteome Science 2011 9:54.

\section{Submit your next manuscript to BioMed Central and take full advantage of:}

- Convenient online submission

- Thorough peer review

- No space constraints or color figure charges

- Immediate publication on acceptance

- Inclusion in PubMed, CAS, Scopus and Google Scholar

- Research which is freely available for redistribution 